\begin{tabular}{|c|c|}
\hline 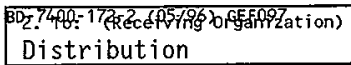 & $\begin{array}{l}\text { 3. From: (Originating organization) } \\
\text { Technical Planning }\end{array}$ \\
\hline $\begin{array}{l}\text { 5. Proj./Prog./Dept./Div.: } \\
\text { Technical Planning }\end{array}$ & $\begin{array}{l}\text { 6. Design Authority/ Design Agent/Cog. } \\
\text { Engr.: } \\
\text { M. I. Wood }\end{array}$ \\
\hline
\end{tabular}

8. Originator Remarks: Requesting Approva]
4. Related EDT No.:

$\mathrm{N} / \mathrm{A}$

7. Purchase Order No.:

$$
\text { N/A }
$$

9. Equip./Component No.: $\mathrm{N} / \mathrm{A}$

10. System/Bldg./Facility:

11. Receiver Remarks: 11A. Design Basel ine Document? [] Yes [X] No $N / A$

$\mathrm{N} / \mathrm{A}$

12. Major Assm. Dwg. No.: $N / A$

13. Permit/Permit Application No.: $\mathrm{N} / \mathrm{A}$

14. Required Response Date: $N / A$

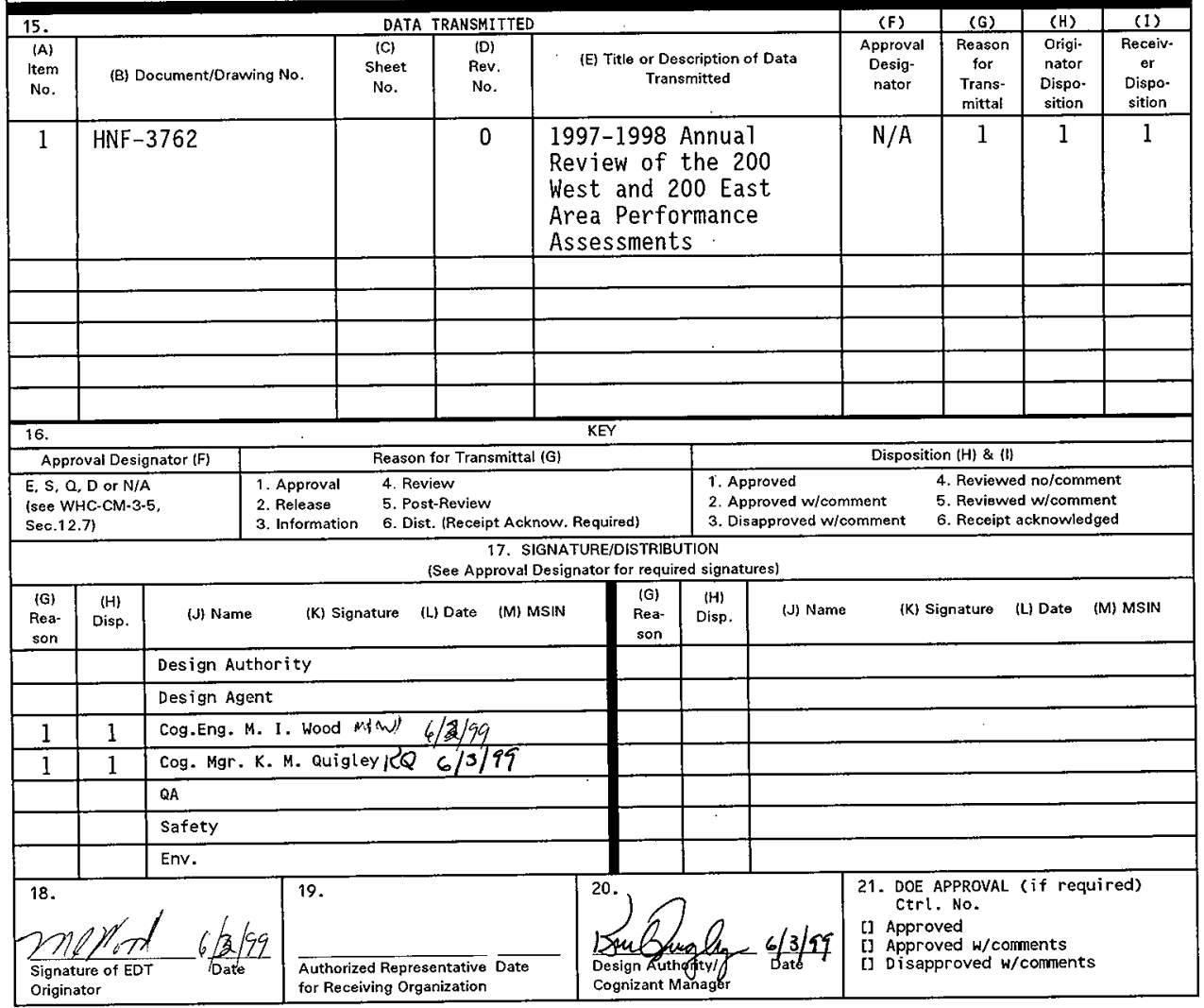




\title{
1997-1998 Annual Review of the 200 West and 200 East Area Performance Assessments
}

\author{
M. I. Wood \\ Waste Management Federal Services of Hanford, Inc., Richland, WA 99352 \\ Richland, WA 99352 \\ U.S. Department of Energy Contract DE-AC06-96RL13200

$\begin{array}{llll}\text { EDT/ECN: } & 618526 & \text { UC: } 500,46-2000 & \\ \text { Org Code: } & \text { R2140000 } & \text { Charge Code: HN970031 } & 101634 / \text { AR00 } \\ \text { B\&R Code: } & \text { EW02J125 } & \text { Total Pages: } 41 \stackrel{\mathrm{cW}-4-89}{6-4}\end{array}$

Key Words: Performance Assessment, 200 Area Low-Level Burial Grounds, DOE order $5820.2 \mathrm{~A}$

Abstract: An annual review of the 200 West and 200 East Area Performance Assessment (PA) analyses for fiscal year 1998 was completed. Burial ground disposal operations were found to be compliant with performance objectives in DOE Order 5820.2A. Other newly generated information and analyses relevant to $\mathrm{PA}$ assumptions and results were surnaxized. This report was initially submitted to the Department of Energy-Richland Office (DOE-RL) as a letter report in october, 1998.

TRADEMARK DISCLAIMER. Reference herein to any specific commercial product, process, or service by trade name trademark, manufacturer, or otherwise, does not necessarily constitute or imply its endorsement, recommendation, or favoring by the United States Government or any agency thereof or its contractors or subcontractors.

Printed in the United States of America. To obtain copies of this document, contact: Document Control Services, P.O. Box 950, Mailstop H6-08, Richland WA 99352, Phone (509) 372-2420; Fax (509) 376-4989.

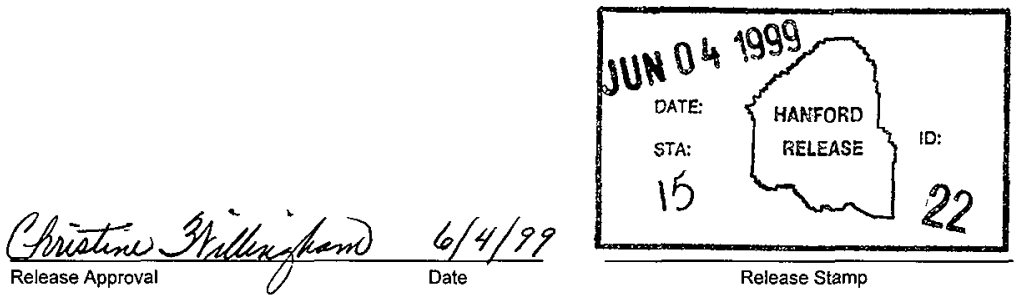

Approved For Public Release 
HNF-3762, Rev, 0

\section{7-1998 ANNUAL REVIEW OF THE 200 WEST AND 200 EAST AREA PERFORMANCE ASSESSMENTS}

M.I. Wood

\subsection{SUMMARY}

In this review, the projected dose estimates of radionuclide inventories disposed in the active LLBG since September 26, 1988 have been provided using the dose methodology developed in the PA analyses. All performance objectives defined in DOE Order 5820.2A (DOE 1988) are currently satisfied and it appears that current waste acceptance criteria and waste acceptance practices are sufficient to maintain compliance with performance objectives. Other data that have recently been collected and have some relevance to primary PA assumptions affecting dose estimates were also reviewed. This information indicates that associated PA assumptions are conservative. Therefore, waste acceptance criteria derived from dose estimates are conservatively low and acceptable.

\subsection{INTRODUCTION}

The Department of Energy (DOE) issued DOE Order 5820.2A, Radioactive Waste Management, on September 26, 1988 to regulate DOE-controlled radioactive waste management practices. In the low-level waste (LLW) chapter of the Order [Chapter III, Section 3.b.(1)], DOE specified that a site specific performance assessment (PA) analysis be completed and then maintained to demonstrate that LLW disposal practices are compliant with performance objectives defined in the Order (Chapter III, Section 3.a). PA analyses (Wood, et al 1995 and Wood, et al 1996) have been completed for both the active 200 West and 200 East Low Level Burial Grounds (LLBG) and both have received conditional approval (Cowan 1996 and Frei 1997 , respectively). Addendums to both PA analyses have also been completed (Wood, 1996 and Wood 1998a). Consequently, the PA effort supporting waste management is now focused on PA maintenance and closing out conditions of approval.

The PA maintenance requirement has been reiterated in an Interim Policy statement (DOE 1996a) and a guidance document has been prepared (DOE 1996b) that defines the primary components of PA maintenance. In response to these requirements and guidance, a PA maintenance plan for the Hanford LLBG has been prepared and transmitted to DOE/RL (Wood 1997). One primary component of the PA maintenance effort is an annual review of the PA 
HNF-3762, Rev. 0

analysis. This is the second annual review of the 200 West and 200 East Area PAs. The primary functions of this review are to evaluate the continued compliance of disposal actions in the previous year with the performance objectives and continued relevance of critical PA assumptions.

In Section 3, the disposed LLW inventory is summarized and the estimated incremental dose from this inventory is provided. Inventory and dose discussions are broken down in terms of specific radionuclides (uranium versus others) and waste type (reactor compartment waste versus other sources) because dose estimating methods are distinct. In Section 4, additional data or information collected on site that has some bearing on the PA assumptions are discussed. These include modeling analyses of radionuclide transport from the LLBG and other 200 Area sources (Section 4.1), additional field evidence of radionuclide transport in vadose zone areas contaminated by tank leaks containing fuel processing waste (Section 4.2), and results from a pilot scale cover test being conducted in the field (section 4.3). Current environmental monitoring results are summarized in Section 5 .

\subsection{SUMMARY OF DISPOSED INVENTORY AND EVALUATION OF DISPOSED INVENTORY IMPACT ON LLBG COMPLIANCE WITH DOE REQUIREMENTS}

Included in this section is a summary description of disposed inventory (Section 3.1), a summary of groundwater and inadvertent intruder dose estimates associated with disposed inventory (Section 3.2), an evaluation of compliance with other performance objectives (Section 3.3), a review of progress towards satisfying PA conditional approval requirements (Section 3.4), and a summary statement of conclusions about compliance with performance objectives (Section 3.5).

\subsection{DISPOSED INVENTORY DESCRIPTION}

Four LLBG in the 200 West Area have received LLW from September 26, 1988 through July 31, 1998. These include 218-W-5, 218-W-3, 2128-W-3AE, and 218-W-4C (Figure 1). Two LLBG in the 200 East Area 218-E-10 and 218-E-12B have also received LLW in this time period (Figure 2). With the exception of reactor compartment disposal in Trench 94, 218-E-12B, the majority of waste has been disposed in the 200 West Area LLBG $\left(52,825\right.$ versus $6103 \mathrm{~m}^{3}$, respectively). The volume of disposed reactor compartments is $61,117 \mathrm{~m}^{3}$. 
HNF-3762, Rev. 0

Waste disposed from August 1, 1997 through July 31, 1998 is considered in this report. Uranium waste is reviewed separately from other mobile radionuclides (e.g., ${ }^{99} \mathrm{Tc},{ }^{129},{ }^{14} \mathrm{C}$ ) because dose estimates for uranium isotopes are more complex than other radionuclides, involving more than one release mechanism (i.e., solubility-controlled release and advection-controlled release). Uranium waste also provides a significant source of potential dose and is more frequently disposed. Reactor compartments disposed in Trench 94 of Burial Ground 218-E-12B are described separately. These wastes are distinct because the waste inventory, the waste material (activated metal), the waste package, and the dose estimating method are a set of factors that make this waste unique.

In Table 1, the disposed inventories are broken down by PA-sensitive radionuclides and by burial ground. Total waste volumes are also provided. These summaries reflect the concentration of disposal activity in the 200 West Area LLBG.

\subsubsection{URANIUM WASTE}

Uranium waste was disposed in a smaller number of trenches (Table 2). The waste inventory is distinguished by one large waste stream from the Fast Flux Test Facility (FFTF). The waste consisted of depleted uranium bricks that were disposed in a HIC in Burial Ground 218-W$3 A E$, Trench 8 . The ${ }^{238} \mathrm{U}$ mass in this waste stream, $2.1 \times 10^{7} \mathrm{~g}$ of ${ }^{238} \mathrm{U}$ and 1163 grams of ${ }^{234} \mathrm{U}$ is approximately $90 \%$ of the total uranium mass disposed in the previous year. Other than these wastes, uranium quantities making up the rest of the inventory were typically in the range of 10 to $10,000 \mathrm{~g}$ per package.

\subsubsection{OTHER MOBILE RADIONUCLIDE}

Mobile radionuclides disposed from August, 1997 through July, 1998 (Table 3) included ${ }^{3} \mathrm{H},{ }^{14} \mathrm{C},{ }^{99} \mathrm{Tc}$, and ${ }^{129} \mathrm{I}$ and generally show the same characteristics as the waste containing these radionuclides disposed previously. As in the earlier time frame, higher activities of tritiated water were disposed on sorbing materials and the primary generator was Princeton Plasma Physics Laboratory (PPPL). The next highest inventory disposed among the suite of mobile radionuclides was ${ }^{9} \mathrm{Tc}$, with a total activity about two orders of magnitude below the total activity of disposed tritium. 


\subsubsection{REACTOR COMPARTMENT WASTE}

Reactor compartment waste generated by the U.S. Navy is disposed only in Trench 94 in 218-E-12B. It was treated separately in the 200 East Area PA because it is a unique waste material and disposed in one location. A list is provided in Table 4 of reactor compartment inventory disposed from August 1, 1997 through July 31, 1998. The difference in inventory reflects the smaller number of compartments disposed in the last year. Reactor compartment waste is primarily activated metal.

\subsubsection{FUTURE WASTE}

Projection of future waste inventories is provided through annual forecasts of future waste to be received at the LLBG. These forecasts are supplied by current generators and entered into the Solid Waste Integrated Forecast Technical (SWIFT) Report, an electronic data base. The latest estimated radionuclide inventory compiled from 1998 and beyond is provided in Table 5. The forecast has changed little relative to last year.

\subsection{PROJECTED DOSE ESTIMATES FROM THE DISPOSED WASTE TO EVALUATE COMPLIANCE WITH DOE ORDER 5820.2A}

Among the performance objectives defined in DOE Order 5820.2A, the primary objective is the all pathways dose limit of $25 \mathrm{mrem} / \mathrm{yr}$ to the maximum exposed individual $100 \mathrm{~m}$ downstream of the disposal facility. In the PAs, a multiple exposure pathway agriculture scenario was used to generate dose estimates that were compared to the $25 \mathrm{mrem} / \mathrm{yr}$ limit. Similarly, a single exposure groundwater consumption pathway was compared to a 4 mrem/yr drinking water limit. With the exception of ${ }^{36} \mathrm{Cl}$, higher relative dose was calculated for each radionuclide in comparison with the $4 \mathrm{mrem} / \mathrm{yr}$ limit (see Table 4-22 in Wood, et al, 1995). This occurred because the dominant dose producing pathway was consumption of contaminated well water.

In the 200 West PA, the $4 \mathrm{mrem} / \mathrm{yr}$ standard was adopted for every radionuclide (including ${ }^{36} \mathrm{Cl}$ ) to compare dose calculations against and determine compliance with DOE Order $5820.2 \mathrm{~A}$. Following the acceptance of the 200 West PA (Cowan 1996), the 200 East PA was completed and conditionally approved (Frei 1997). In the 200 East approval, DOE-HQ determined that ${ }^{36} \mathrm{Cl}$ inventory and associated dose had to be compared to the $25 \mathrm{mrem} / \mathrm{yr}$ all pathways limit. Thus, the

${ }^{36} \mathrm{Cl}$ all pathways cose has been considered in this review. Given the ${ }^{36} \mathrm{Cl}$ inventory in disposed 
waste, ${ }^{36} \mathrm{Cl}$ provides no significant portion of projected dose $\left(\leq 3 \times 10^{-7} \mathrm{mrem} / \mathrm{yr}\right)$, regardless of groundwater pathway limit considered.

Compliance was based on dose estimated for the entire facility as it now exists, including proposed contiguous extensions of the facility that have not actually been utilized (e.g., the 218W-5 extension). In the 200 East Area, inventory disposed in the two active LLBG (218-E-10 and $218-E-12 B$ ) were considered separately because they are geographically separated and the groundwater modeling analyses suggest that contaminant plumes from each burial ground should not commingle.

The next most significant performance objective in the DOE Order 5820.2A is the inadvertent intruder limit. A dose limit of $100 \mathrm{mrem} / \mathrm{yr}$ from chronic exposure or $500 \mathrm{mrem} / \mathrm{yr}$ for acute exposure was defined for an inadvertent intruder who might be exposed to waste in the disposal facility. In the PAs, it was shown that the $100 \mathrm{mrem} / \mathrm{yr}$ chronic dose limit was the more limiting alternative. Therefore, the chronic exposure standard was adopted to compare dose results against and establish waste acceptance criteria. These criteria are quantified as radionuclide specific concentration limits per trench. Compliance with the performance objective was based on waste volume disposed in a trench. The trench by trench breakdown was not provided in either PA, but a total burial ground dose was provided in which radionuclide concentrations were calculated on the basis of total burial ground inventory and total waste volume disposed. Both trench by trench and total burial ground estimates are provided here.

Dose estimates from the inventory listed in Tables 1 through 5 are summarized and explained below for each of the primary criteria. The dose estimates assume that Category 3 conditions will ultimately be the end state condition (e.g, a final burial ground cover that limits infiltration to no more than $0.5 \mathrm{~cm} / \mathrm{yr}$ is placed over the disposal trenches). Waste disposal configurations that have enhanced isolation from the geohydrologic environment (primarily placement in HICs or equivalent) have also been incorporated into the calculations.

\subsubsection{GROUNDWATER DOSE ESTIMATES}

In the PAs, a methodology was developed to evaluate groundwater dose for any size disposal facility of interest (Section 3.2.3.1 in Wood et al, 1995 and Section 3.2.1.2 in Wood et al, 1996). This approach was taken to facilitate evaluation of future changes in disposal facility size that cannot be predicted. In addition to the burial ground dose estimates used to evaluate compliance with DOE Order $5820.2 \mathrm{~A}$, the methodology has been used to evaluate dose on a 
HNF-3762, Rev. 0

trench by trench basis in the 200 West Area LLBG as an aid to the routine day to day waste acceptance process. These results are also provided in this section.

Burial Ground Drinking Water Dose Estimates

When calculating contaminant release and transport, it was necessary to make numerous averaging and simplifying assumptions because many environmental heterogeneities are present that cannot be characterized or modeled realistically. To calculate the groundwater drinking or all pathways dose, a modeling assumption of uniform radionuclide distribution across the disposal facility axis perpendicular to the general direction of groundwater flow was assumed, even though it is known that there are specific waste volumes with much higher concentrations of contaminants. It is theoretically possible for the hypothetical individual using contaminated groundwater immediately downstream from the high concentration zone to receive a larger dose than one predicted by averaging. However, the likelihood that the individual would actually drill a well and consume water from the precise location downstream from the highest concentration zone during the time of peak groundwater concentration is considered quite small and perhaps physically impossible considering the natural mixing tendencies of water. Therefore, it was concluded that the averaging assumption was reasonable when evaluating compliance.

This approach does not explicitly model the current time period in which the LLBG are only covered with an interim cover which probably permits greater average recharge than that assumed for Category 3 conditions. Qualitative arguments have been made in the PAs (Section

\subsubsection{1 of Wood et al 1995 and Section 3.2.3.1 of Wood et al 1996) that conservative} assumptions used in the model counteract this potentially nonconservative condition. Further, most waste packages used since September 26,1988 are sufficiently sturdy to prevent contact of infiltrating water with radionuclides for the operational period such that minimal release is expected prior to placement of the final cover several decades from now. This is particularly the case with Category 3 wastes that are placed in sealed concrete boxes and contain the majority of the PA sensitive inventory. Finally, in the composite analysis (CA) completed this year by Kincaid, et al (1998), a sensitivity case was considered in which an enhanced recharge rate of $7.5 \mathrm{~cm} / \mathrm{yr}$ through the LLBG was assumed during the operations period ( 40 years) followed by infiltration rates controlled by a final cover $(0.5 \mathrm{~cm} / \mathrm{yr})$. They concluded that the brief period of increased infiltration had no real effect on estimated downstream groundwater concentrations and, therefore, dose estimates. 
In Table 6, the dose estimates are broken down into the three LLBG groups, three different time periods, and uranium dose and other radionuclide dose. Dose estimates due to inventory disposed since the inception of the DOE Order 5820.2A through 7/3//1997 (prepared in the previous annual report [Wood 1998b]), from 8/1/1997 through 7/31/1998 (the focus of this report), and from projected future inventory are provided. By summing the dose estimates from all three time periods, a total dose estimates for the LLBGs is provided. The contribution from reactor compartments is not explicitly counted in the $218-\mathrm{E}-12 \mathrm{~B}$ dose estimate, because it is calculated to be very small $(<0.0001 \mathrm{mrem} / \mathrm{yr}$ ) relative to the $4 \mathrm{mrem} / \mathrm{yr}$ dose.

The total dose for each burial ground group when compared to a $4 \mathrm{mrem} / \mathrm{yr}$ limit shows compliance with the performance objective has been maintained. The projected dose from future inventory estimates has not changed since the last year's annual report and the relative increase in overall dose estimate from this year's disposal is small. If dose from projected inventory is ignored, the dose increments due to waste disposed this year are $3 \%$ and $4.5 \%$ for West Area and 218-E-10, respectively. Given the emphasis on LLW disposal in the 200 West Area LLBG since September, 1988, the projected doses from 200 West inventory are noticeably larger than those projected from inventory disposed in the 200 East Area.

The dose contribution from uranium inventory in the overall dose estimate is historically dominating and continues to dominate in this year's reported inventory. At the same time, the incremental increase in dose estimate from this years disposed uranium waste is small relative to previously disposed uranium ( $<2 \%$ ). This trend is expected because of continued disposal of uranium in concrete $\mathrm{HICs}$, a disposal condition that minimizes dose estimates for uranium. Now that wastes containing large inventories of uranium are routinely placed in concrete HICs, future projected doses from uranium wastes are expected to be greatly reduced, as shown by the projected uranium doses (Table 6).

The columns identified as estimated dose are generated from estimates of mobile radionuclide inventory (not including uranium) which may be present at trace levels but have not been reported or measured. In the 200 East PA (Wood et al, 1996), a scaling factor was employed based on the reactor production ratios estimated from various sources (Appendix $B$ ). The ratio of individual radionuclides to reported total beta/gamma activity was used to calculate unknown inventory. The concept is that, in lieu of direct characterization information, the unknown mobile radionuclide inventory can be conservatively estimated by assuming that reactor production ratios are maintained in waste. 
In this estimate, mobile radionuclide to ${ }^{137} \mathrm{Cs}$ ratios were used. This scaling method is comparable to the beta/gamma scaling factor and calculates essentially the same mobile radionuclide quantities. In the 200 East $\mathrm{PA}$, the straight ratio was used to calculate unreported inventory. This is expected to be an overly conservative ratio due to the fact that the primary source of large ${ }^{137} \mathrm{Cs}$ inventory waste streams are from B Plant, whose purpose was to separate ${ }^{137} \mathrm{Cs}$ (and ${ }^{50} \mathrm{Sr}$ ) from dissolved fuel, thereby increasing the ${ }^{137} \mathrm{Cs}$ and ${ }^{90} \mathrm{Sr}$ concentrations relative to the other radionuclides. However, until more information is gathered to determine the B Plant mobile radionuclide inventory, this estimate will continue to be used.

The estimated inventories are based on the ${ }^{137} \mathrm{Cs}$ disposed in the active trenches during the time periods evaluated. Using these assumptions, the projected doses from estimated radionuclides are of the same order of magnitude or less of the dose estimated from reported inventories. In this year's inventory, the dose from estimated mobile radionuclide inventory is a fraction of the previously estimated dose (about $4 \%$ ) and reflects that fact that no major source of ${ }^{137} \mathrm{Cs}$ provided waste to be disposed.

Estimate of potential dose from future inventories is highly speculative in a number of ways. First, the accuracy of the projected inventories is impossible to determine. Second, the need for and use of waste form performance cannot be known. In this projected inventory, there is a large ${ }^{129} /$ component which dominates the dose estimate. If the ${ }^{129} /$ waste were disposed without waste form performance, a very large dose of $3.2 \mathrm{mrem} / \mathrm{yr}$ would result. Consequently, if such an inventory were proposed for disposal in the LLBG, disposal methods would be devised to ensure that the projected dose from the ${ }^{129} /$ sources would be much less than $3.2 \mathrm{mrem} / \mathrm{yr}$. In this estimate, we have assumed that the projected dose from these sources would be reduced by a factor of 10 to $0.32 \mathrm{mrem} / \mathrm{yr}$.

\section{Trench by Trench Dose Calculations for the 200 West Area LLBG}

Dose estimates are also broken down by trench in the 200 West Area LLBG, the goal being to prevent exceedance of the $4 \mathrm{mrem} / \mathrm{yr}$ limit for any trench. The trench by trench calculations are completed as part of the waste acceptance process. They are not a part of compliance demonstration but a means of ensuring that day to day waste disposals will not cause a cumulative exceedence of the overall burial ground limit. This strategy works because dose calculations are proportional to inventory distribution assumptions and become larger as the assumed inventory distribution becomes more restrictive (e.g., when the trench by trench 
HNF-3762, Rev. 0

analysis is done). This approach does not work for the 200 East Area LLBG because the trench orientation is not appropriate and total burial ground inventory must be considered.

The trench by trench groundwater dose projections are summarized in Table 7. The dose calculation methodology is identical to the whole burial ground calculations discussed above except that trench specific waste inventories, waste volumes and waste areas are considered one trench at a time. Doses are provided for each trench for the two time periods that include all disposed waste. Also, a total dose is also provided. Uranium doses are provided separately from other mobile radionuclides.

All trenches have projected dose estimates that fall below the $4 \mathrm{mrem} / \mathrm{yr}$ goal. As with the overall LLBG dose estimates, the uranium contribution to dose tends to be dominant. Of the mobile radionuclides, ${ }^{99} \mathrm{Tc}$ and ${ }^{14} \mathrm{C}$ are the most significant when looking at all the trenches.

\subsubsection{INADVERTENT INTRUDER DOSE ESTIMATES}

Compliance with the inadvertent intruder performance objective is determined by comparing projected intruder dose from a trench waste volume and inventory with a $100 \mathrm{mrem} / \mathrm{yr}$ chronic dose limit. Occasionally, individual waste packages are received that approach or exceed the Category 3 limits. In these cases, written justification for alternative waste concentration averaging is provided to the waste disposal organization by the PA contact. The likelihood that an inadvertent intruder would exhume the particular package with the high concentration inventory is considered very small and that averaging over a trench volume is a reasonable approach to compliance evaluation. As with the groundwater dose evaluation, the Category 3 conditions are assumed to exist postclosure. The results are summarized in Table 8 . Separate time periods are not considered for these estimates because the calculated doses apply to cumulative inventories and waste volumes.

In Table 8, trench volumes, activities of largest contributors and the dose fractions are provided. Dose estimates are 100 times the sum of the dose fractions. In most cases, dose estimates are $<1 \mathrm{mrem} / \mathrm{yr}$, far below the $100 \mathrm{mrem} / \mathrm{yr}$ limit. Where uranium is present in significant quantities, it provides the largest projected dose. The clearest example of the uranium waste influence is in $218-W-3 A E$, trench 8 . Otherwise, ${ }^{137} \mathrm{Cs}$ and/or ${ }^{90} \mathrm{Sr}$ provide the largest dose. Of the individual waste packages received and disposed in the last time period (August, 1997 through July, 1998), no waste exceeded Category 3 limits on a per package ( 55 gallon drum) basis. 
HNF-3762, Rev. 0

A projected total burial ground inadvertent intruder dose is provided in Table 9 that is consistent with those provided in the PAs. On this scale of waste volume averaging, the estimated doses for each burial ground are well below the limit.

\subsection{OTHER PERFORMANCE OBJECTIVES}

Two other limits were considered in the PA analyses, the air emissions dose limit of 10 $\mathrm{mrem} / \mathrm{yr}$ and a radon flux limit of $20 \mathrm{pCi} / \mathrm{m}^{2} \mathrm{~s}$. These are provided in Table 9 along with the summary of the groundwater contamination and inadvertent intruder doses. In the PA analyses, the potential sources of air contamination were concluded to be ${ }^{14} \mathrm{C}$ and ${ }^{3} \mathrm{H}$. Given the limited inventory of ${ }^{14} \mathrm{C}$, the decay of ${ }^{3} \mathrm{H}$, and the partitioning of both elements between liquid and gas, it was shown that dose estimates would be very small (Section 4.3.1 of Wood et al 1995). In the case of a Category 3 closure condition assumption (exposure at 500 years), it was concluded that the conditions needed for ${ }^{14} \mathrm{C}$ to provide atmospheric dose were unrealistic and ${ }^{3} \mathrm{H}$ would have decayed to trivial amounts. Therefore, no dose from atmospheric.release was projected.

Using the analytical solutions developed in the PA for radon flux (Section 4.3.1 of Wood, et al 1995), and the uranium inventories in the three burial ground groups, the largest calculated radon flux was $0.033 \mathrm{pCi} / \mathrm{m}^{2} \mathrm{~s}$ in the 200 West Area. In the 200 East Area, the projected doses and radon flux are orders of magnitude smaller.

\subsection{CONDITIONAL APPROVAL REQUIREMENTS}

In the previous annual review (Wood 1998b), all requirements for final PA approval were identified as completed with the exception of two. The first was completion of a composite analysis (CA) and the second was a review of waste characterization effort by generators for waste disposed at the LLBG. The CA has been issued and sent to DOE-HQ for review. Aspects of the CA that relate to the PAs and performance of the LLBG are described below (Section 4.1.1).

A formal review of waste characterization has not been completed because waste characterization efforts tied to waste acceptance practices that have been recently revised by Waste Management Hanford. A more structured documentation system is being put into place that should be incorporated into a current and accurate review of waste characterization efforts. Particular attention is being given to discussions of radioisotopes defined by the PAs as sensitive to long-term LLBG performance. The evaluation of waste characterization efforts will be completed in fiscal year 1999. 
HNF-3762, Rev. 0

\subsection{CONCLUSIONS}

It is concluded from this review that disposal practices and waste inventories disposed in the active LLBG are in compliance with performance objectives. The current waste disposal procedures and waste management practices are sufficient to maintain compliance with the performance objectives.

\subsection{REVIEW OF ADDITIONAL INFORMATION PERTINENT TO PA ASSUMPTIONS}

Additional information has been generated in various projects that has some bearing on the PA assumptions influencing radionuclide mobility in the natural environment. Data has been developed in the areas of contaminant transport modeling, vadose zone contaminant characterization efforts, and cover performance. This information is summarized and its relevance to the PA assumptions and dose estimates is discussed.

\subsection{MODELING ANALYSES AND RESULTS}

Two studies were completed that are relevant to contaminant release from the LLBG and transport to the underlying aquifer. The first was the composite analysis (CA) completed by PNNL staff (Kincaid et al 1998), a study that evaluated releases from multiple waste sources on the 200 Area Plateau, including the LLBG, to estimate the generation of site-wide groundwater contaminant plumes from commingled sources. The second was a series of sensitivity analyses completed to evaluate far-field propagation of groundwater contaminant plumes from the LLBG only (Lu 1997 and Lu 1998).

\subsubsection{SYNOPSIS OF CA WORK THAT RELATES TO LLBG PERFORMANCE}

\section{Summary of Results}

The Defense Nuclear Facility Safety Board (DNFSB) reviewed the DOE low-level waste management program in 1994 and noted that, while long-term environmental contamination estimates from the disposal of low-level waste at an individual site were being completed, no attempt was being made to evaluate the potential for enhanced environmental contamination that might result from the commingling of radioactive releases from multiple waste sites located in the vicinity of low-level waste sites. The underlying concern was that allowable waste inventories are 
being determined for the individual sites may be too high when considering allowable inventories for the entire site. The $\mathrm{CA}$ is the first evaluation that addresses this issue.

The analysis projected contamination estimates about 2,000 years beyond closure of the Hanford Site, and, per DOE guidance, focused on projected environmental contamination occurring over a 1,000 year period following closure. The most important pathway turned out to be groundwater contamination. Radionuclide releases from most of the waste sites existing on the 200 Area Plateau were projected by assuming radionuclide release from each waste site into the unconfined aquifer directly underneath the site. Flux into the aquifer was quantified on the basis of starting inventory from a given waste site and a release model considered most appropriate for the waste type. Subsequent movement of contaminants through the aquifer was modeling using the CFEST computer code, a three dimensional site-wide groundwater model. The code has been used to simulate current contaminant plume distributions and also estimates future changes in groundwater movement patterns as the effects of previous Hanford Site liquid discharge practices (e.g., groundwater mounds created by U-Pond and B-Pond) dissipate with time.

Estimates of peak groundwater contamination at locations between a waste exclusion zone boundary (near the 200 West and East Area boundaries) and the Columbia River were evaluated as a function of time (up to about 2000 years postclosure). Based on the timing and extent of peak groundwater contamination in this region, dose to man calculations were completed. Several groundwater use scenarios were considered and calculated doses were compared with a $100 \mathrm{mrem} / \mathrm{yr}$ maximum allowable dose rate. These included recreational, residential, industrial, and agricultural scenarios. Of these, for the same groundwater peak concentrations, the greatest dose was calculated for the agricultural scenario. In this scenario, dose was received through the consumption of contaminated water, crops, and meat.

Like other waste sites, current and future waste inventories by specific isotope from the LIBG were requested by the analysts as source term input data. Only well known environmentally mobile radionuclides were modeled in the analyses. Selection of these radionuclides was based on previous analyses and available laboratory and field data. The mobile radionuclides list included ${ }^{36} \mathrm{Cl},{ }^{99} \mathrm{Tc},{ }^{129}$, uranium isotopes, ${ }^{14} \mathrm{C}$ and ${ }^{79} \mathrm{Se}$. These are also the radionuclides in the PA analyses considered most likely to contaminate groundwater. Inventory data for the LLBG used in the composite analysis were taken from the most current Solid Waste Information Tracking System (SWITS) data base. 
In the CA, future inventory of mobile radionuclides was estimated by extrapolating the current inventory disposed between September 26, 1988 and December 31, 1996 out to the year 2027. Mobile radionuclide inventories were then estimated by taking the product of the estimated ${ }^{137} \mathrm{Cs}$ inventory and the mobile radionuclide to ${ }^{137} \mathrm{Cs}$ ratio. This ratio was based on average Hanford reactor production ratios for 10 -year old spent fuel. The most significant radionuclide in the $\mathrm{CA}$ analysis turned out to be ${ }^{99} \mathrm{Tc}$. Its inventory estimate, $51.5 \mathrm{Ci}$, is larger than the inventories projected in the PA analyses (a maximum of $15.1 \mathrm{Ci}$ ) and in this annual review $(31.5 \mathrm{Ci})$.

The release rate model selected for solid waste in the CA was the soil/debris model, a conservative model that assumes all inventory is available for dissolution in leaching groundwater. A desorption coefficient was assumed for each radionuclide, with any $K d$ value greater than 0 $\mathrm{mL} / \mathrm{g}$ retarding the flux of that radionuclide relative to groundwater flux. Sorption values of 0,0 , $0.5,3,5$, and 0 were assumed ${ }^{36} \mathrm{Cl},{ }^{99} \mathrm{Tc}$, ${ }^{129}$, uranium isotopes, ${ }^{14} \mathrm{C}$ and ${ }^{79} \mathrm{Se}$. Given these conditions, only the nonsorbing radionuclides $\left({ }^{36} \mathrm{Cl},{ }^{99} \mathrm{Tc}\right.$, and $\left.{ }^{79} \mathrm{Se}\right)$ were predicted to reach groundwater in the 2000 year time frame post closure. Of these, ${ }^{99} \mathrm{Tc}$ was the only substantial contributor to far-field groundwater contamination. The release rate assumptions caused discharge of inventory from the LLBG to lag behind liquid discharge sources (cribs, ponds, ditches, tank leaks) and solid waste disposed in the LLBG before 1988. Estimated travel times through the vadose zone were 650,1150 , and 1054 years for $218-E-12 B, 218-E-10$, and the 200 West Area LLBG, respectively for non sorbing radionuclides.

Waste inventories calculated to discharge into the vadose zone were then propagated via the three dimensional groundwater model for 2000 years into the future. All groundwater areas between the edge of the buffer zone and the Columbia River were examined to determine the time and place of maximum contamination and associated dose estimates. The fundamental conclusion from the analysis was that dose associated with the current groundwater contamination is the maximum that will occur. Generally, few analyses were completed to evaluate the contribution of any given site because of the large number of sites considered. One figure is presented in the CA (Figure 4.34 ( $\mathrm{k}$ )) showing the maximum dose from Tc-99 originating in the LLBG, from both pre- and post- 1988 disposed waste. The estimated maximum dose was $<2$ mrem/yr assuming an agricultural exposure scenario and that maximum was associated with releases from the inactive LLBG. Estimated doses due to the active LLBG versus the inactive LLBG inventories were not be distinguishable. The total dose was $<1 \mathrm{mrem} / \mathrm{yr}$. 


\section{Comparison of the CA with PA analyses}

The CA and PA analyses were intended to be complementary, but not identical in modeling approach. The PA analyses evaluated dose near the disposal facility. The CA evaluated dose at a much greater distance from the disposal facility and included contributions from other sources. Because of the difference in scale, the analytical approaches used in the PA analysis versus the CA could not be identical. The PA analyses modeled two-dimensional vertical cross sections through representative slices of disposal trenches. Contaminant transport through both the vadose zone and the unconfined aquifer up to $100 \mathrm{~m}$ downstream of the disposal trench were modeled explicitly and continuously. In contrast, the site-wide model is a three dimensional model that explicitly models only the unconfined aquifer with estimates of contaminant flux from the vadose zone being an input parameter. Numerical grid spacing was necessarily several times larger in the CA model because of the larger geographical area analyzed and the computing time limitations. Because of these differences, the results of the analyses are best compared in terms of compliance with respective dose limits.

Other differences in the PA analyses versus the $\mathrm{CA}$ are the selections of different values for parameters affecting groundwater concentration estimates. These include infiltration rates, inventory estimates, and sorption coefficients. The nature of these differences and their impact on groundwater contamination estimates are summarized below.

In the PA analyses, two infiltration rate scenarios were considered, each assuming a constant rate $(5$ and $0.5 \mathrm{~cm} / \mathrm{yr})$. The larger rate is associated with a nonvegetated gravel cover and the lower rate is associated with a more structured cover that includes a vegetated surface as the primary infiltration controlling layer. The lower rate is expected to be the most likely rate that can be assumed postclosure because some version of a vegetated cover will almost certainly be the closure cover. In the $\mathrm{CA}$, a two part infiltration rate history was assumed. Infiltration rates for the operational period ( 30 years into the future) and the postclosure period of 7.5 and $0.5 \mathrm{~cm} / \mathrm{yr}$, respectively, were assumed. The larger operational rate reflects the use of a non engineered interim cover that consists of trench fill placed over the waste packages to a depth of 8 feet. The dual infiltration assumption will increase travel time through the vadose zone, but a comparison of travel time estimates between the CA and the PA showed very little difference.

Estimated total mobile radionuclide inventory in the LLBG in the CA versus PA analyses differed for two reasons. First, current inventory estimates are dependent on the time when analyses are completed. In this case, PA analyses were completed earlier and LLBG inventories 
were smaller. Second, different approaches were used to estimate future inventories of mobile radionuclides. These include the following:

- In the 200 West PA analysis, future projections were based on proposed future volumes of disposed waste and the ratio of mobile isotopes to volume disposed after September 26 , 1988.

- In the 200 East PA analysis, waste volume projections and scaling factors based on the estimated total beta/gamma inventory were used to estimate final mobile radionuclide inventory. The ratio of total beta/ gamma inventory to the radionuclide of interest was determined from average radionuclide-specific Hanford reactor production data. Multiplying this ratio by the extrapolated total beta gamma inventory yjelded estimates of mobile radionuclide inventory.

- In the previous LLBG PA annual review, inventory from waste forecasting data provided by the generators was used to come up with a final inventory estimate.

- In the $\mathrm{CA},{ }^{137} \mathrm{Cs}$ was used as the scaling factor to calculate unreported and future mobile radionuclide inventory. Total ${ }^{137} \mathrm{Cs}$ was estimated by linearly extrapolating the ${ }^{137} \mathrm{Cs}$ final inventory 30 years into the future. This number was multiplied by the mobile radionuclide to ${ }^{137} \mathrm{Cs}$ ratio to come up with a total inventory estimate.

All of these approaches taken are rational and can be used to estimate future inventory. None can be demonstrated to be superior to another, particularly with regard to mobile radionuclides which are generally present in trace quantities, if at all.

The net effect of these approaches was assumption of a larger ${ }^{99} \mathrm{Tc}$ inventory in the CA and greater mobility of the ${ }^{99} \mathrm{Tc}$ inventory overall. The PA analyses treated ${ }^{99} \mathrm{Tc}$ mobility differently, depending on actual disposal conditions of specific waste streams. The CA, because of its broader analysis scope, treated the ${ }^{99} \mathrm{TC}$ inventory uniformly and ultimately predicted greater contamination from the LLBG ${ }^{9} \mathrm{~T} c$ source than the PA analyses.

Finally, the PA analyses and the CA selected different $K d$ values for some of the mobile radionuclides. In the PA analyses, all mobile radionuclides were assumed to be chemically unreactive in the soil column and aquifer $(\mathrm{Kd}=0 \mathrm{~mL} / \mathrm{g})$. This contrasts with the CA assumptions where small positive $\mathrm{Kd}$ values were assigned to uranium, ${ }^{129}$, and ${ }^{14} \mathrm{C}(3,0.5$ and $5 \mathrm{~mL} / \mathrm{g}$, respectively). The result of these assumptions was that none of these isotopes were predicted to reach the aquifer in the 2000 year time frame and ${ }^{99} \mathrm{Tc}$ was the only contaminant released from the LLBG to be a source of projected dose above a negligible value. 
HNF-3762, Rev. 0

The impact of variable parameter selection between the PA analyses and the CA is variable or unquantifiable. The selection of dual infiltration rates in the CA versus a single average rate (PA analyses) has no quantifiable effect on travel time. Consequently, it is unlikely to have an effect on peak groundwater contamination estimates. The larger ${ }^{99} \mathrm{Tc}$ inventory in the CA should result in a larger dose estimate than projected in the PA analyses but the delta cannot be quantified. Because the point of compliance in the CA is much farther from the source, dispersion effects reduce peak concentrations. Also, contributions from other sources to groundwater contamination at the point of compliance in the CA cannot be distinguished from LLBG sources alone. Finally, the CA analysis does not project dose from uranium and ${ }^{129}$ because of the assumption of positive $\mathrm{Kd}$ values. These isotopes are significant contributors to PA dose estimates along with ${ }^{99} \mathrm{Tc}$. From this perspective, the PA analyses provide a conservatively higher dose estimate than does the CA.

These differences in analytical approach are within the range of natural system heterogeneities. Dose estimates at a chosen point of compliance are small relative to dose limits in both PA analyses and the CA, even though different isotopes are predicted as contributors. The $\mathrm{CA}$ results support the expectation that imposition of stringent dose limits near the LLBG (4 mrem/yr drinking water limit and $25 \mathrm{mrem} / \mathrm{yr}$ all pathways) ensures that larger dose limits at the site boundary (100 mrem/yr all) will prevent a significant contribution to far-field groundwater contamination from LLBG radionuclide releases. These results increase confidence that LLBG operations and disposal criteria adequately protect the environment.

\subsubsection{SENSITIVITY ANALYSES OF FAR-FIELD GROUNDWATER CONTAMINATION DUE TO RADIONUCLIDE RELEASE AND TRANSPORT FROM THE LLBG}

In the PA analyses the point of compliance for evaluating groundwater contamination and associated dose due to leaching of radionuclides from the LLBG into the underlying soil column is $100 \mathrm{~m}$ downstream, very near the source. There is also a need to understand the potential for groundwater contamination from this source at the Hanford Site boundary or a variety of locations that might ultimately become the Hanford Site boundary. These potential points of compliance are kilometers away from the LLBG. For this reason, sensitivity analyses similar in approach to the CA were completed to evaluate relative contamination and associated dose at several points in the Hanford Site further downstream of the three LLBG sites (West Area, 218-E-10, and 218-E$12 B)$. These analyses were narrower in scope than those in the CA because only releases from the LLBG were considered. 
HNF-3762, Rev. 0

A series of sensitivity analyses were completed (Lu 1997 and Lu 1998). A site-wide groundwater model application of the computer code, VAM3D-CG, was used to complete the numerical simulation. For any given run, a hypothetical radionuclide release flux into the unconfined aquifer was assumed to occur at the water table directly underneath a primary burial ground area, ignoring the effects of transport through the vadose zone. The source was a constant solution concentration of a generic radionuclide distributed over an area approximating the burial ground area at the water table. Vadose zone migration was not analyzed.

Subsequently, the contaminant was propagated downstream using hydrogeologic characteristics gathered for the Hanford unconfined aquifer system as input parameters (e.g., recharge and discharge locations, hydraulic properties of the unconfined aquifer sediments, aquifer thickness, etc.). Arbitrary well locations were picked for interrogation along the estimated major flow paths (Figure 3) and groundwater concentrations were tracked at those locations for 1000 years after release into the aquifer.

The primary parameters varied in the analyses were infiltration rate, burial ground source, and steady-state hydrologic conditions versus transient mode. Infiltration rates of 5 and $0.5 \mathrm{~cm} / \mathrm{yr}$ were assumed in different runs. These are the same rates evaluated in the PA analyses. Releases were assumed to occur under $218-W-5$ in the 200 West Area, 218-E-10 and 218-E$12 B$.

Both steady-state and transient conditions were evaluated, all except one of the runs being completed in the steady state mode. In the steady state mode, the influences of Hanford liquid discharge were eliminated and the final steady state condition was approximated (water table elevation and flow directions were unchanging). In the transient mode, current hydrologic features, primarily groundwater mounds under U-Pond and B-Pond, were part of the initial conditions. These features were allowed to dissipate over time according to the hydraulic forces assumed in the model. Over time, water table elevations changed and general flow directions adjusted in the transient mode analysis. Contaminants were released into the aquifer at time zero. By comparing estimated groundwater concentrations with time at the hypothetical downstream wells with all other conditions kept constant except for steady state versus transient conditions, the effects of these conditions on groundwater contamination levels was evaluated.

The model generated contaminant plumes from the selected LLBG source. Results were provided in two ways. The first was a map view of the plume with concentration isotherms for a given time after the initiation of release into the aquifer. In Figure 4, an example of one run analysis is provided. In this example, a generic radionuclide at a concentration of $3.7 \times 10^{-6} \mathrm{Ci} / \mathrm{m}^{3}$ 
HNF-3762, Rev. 0

over an area beneath 218-W-5 was released for the duration of the run. The infiltration rate was 5 $\mathrm{cm} / \mathrm{yr}$ and the plume position is that estimated for 2996,1000 years after radionuclide release into the unconfined aquifer began. In figures 5 and 6 , the groundwater concentrations of the generic radionuclide over time at the various hypothetical wells is plotted. Because the source originated in West Area, two general paths are taken by the advancing plume, one north through the Gable Mountain gap through wells W1 and W2, and one east towards the Columbia River through wells W3 through W6. This observation also holds true for the $218-\mathrm{E}-10$ source which is upstream of all the wells. However, if the source area is $218-\mathrm{E}-12 \mathrm{~B}$, only wells W3 through W6 are downstream.

In Figures 5 and 6, the development of a steady-state concentration condition is shown over time in the two wells nearest the source, W1 and W2. A trend toward steady-state concentrations in wells W3 through W6 is developing but the calculation was not continued far enough into the future to see its complete development. This pattern must occur because the steady state flux of contaminant into the unconfined aquifer lasts the entire time of analysis. The steady state concentration will develop at all points in the unconfined aquifer at some time, depending on distance from the source, and persist until the source term is truncated. The second observation is that the maximum groundwater concentration decreases with distance from the source. This effect is also expected because the tendency for dispersion effects to dilute solution concentrations with distance from the source.

The approximate maximum well concentrations for all the analytical conditions evaluated are summarized in Table 10. The dilution effects are quantified by comparing these maximum concentrations with the starting solution concentration $\left(3.7 \times 10^{-6} \mathrm{Ci} / \mathrm{m}^{3}\right)$ entering the unconfined aquifer assumed in all the analyses. The ratio of this value to the maximum concentrations indications the degree of dilution expected to occur at the far field wells. The dilution factors also indicate relative decreases in estimated dose because dose is linearly proportional to groundwater concentration. The following observations are relevant:

- The reduction in maximum concentration is minimal at the closest well to a burial ground for the highest infiltration rate. This occurs in the case where discharge of contaminants from 218-E-12B at an infiltration rate of $5 \mathrm{~cm} / \mathrm{yr}$ intercepts well W3, a distance of 500 to $1000 \mathrm{~m}$. In this case, the reduction factor is about 7 -fold (ratio of starting to maximum concentration). Under these conditions flux into the aquifer is maximized because of the higher infiltration rate. Dispersion effects are minimal because the plume has not traveled a long distance. 
HNF-3762, Rev. 0

- The reduction factor increases with increasing distance. Maximum contaminant concentrations reaching well W4 from 218-E-12B (about $8000 \mathrm{~m}$ downstream) are a factor about 4 times lower than those at well W3, increasing the reduction factor to about 30 -fold.

- Reducing the infiltration rate by a factor of ten reduces the estimated flux into the unconfined aquifer and the maximum concentration by the same amount. The minimum reduction of maximum concentration assuming an infiltration rate of about $0.5 \mathrm{~cm} / \mathrm{yr}$ is estimated to be about 70-fold.

- The effect of transient versus steady-state hydraulic conditions has an inconsequential effect on peak groundwater and associated dose estimates.

These results permit a rough quantitative estimate of maximum potential contributions of LLBG radionuclide releases to groundwater at potential Hanford Site boundaries relative to the $100 \mathrm{mrem} / \mathrm{yr}$ limit that has been assumed as acceptable in DOE Order 5400.5 at a site boundary. Future site boundaries are clearly not defined, but a relatively conservative (nearby) boundary near the 200 Areas has been defined by a group of stakeholders (HFSWG 1992) was used to define a closest boundary to the 200 Area sources. For the northward path defined by the sitewide groundwater model (Figure 3 ), this boundary falls between wells $W 1$ and W2. For the eastward path, this boundary lies between W3 and W4. These results support the expectation that the 200 West Area, being further from potential future Hanford Site boundaries, will contribute the least amount of contamination.

If the far-field boundary is assumed to be between W1 and W2 or W3 and W4, the minimum dilution factor for conditions analyzed occurs with inventory released from 218-E-12B and passing east through the buffer zone boundary just east of the disposal site near w3 (about $1000 \mathrm{~m}$ from the source). If the standard infiltration rate of $0.5 \mathrm{~cm} / \mathrm{yr}$ is assumed (engineered final cover), the dilution factor is 74 . Assuming a maximum all pathways dose of $1.65 \mathrm{mrem} / \mathrm{yr}$ calculated to date (Table 9), the far-field contribution to dose would be $0.02 \mathrm{mrem} / \mathrm{yr}$. In comparison with a site-wide limit of $100 \mathrm{mrem} / \mathrm{yr}$, the contribution from LLBG releases are estimated be inconsequential.

For completeness of discussion, it is worth mentioning that the northward transport path is not projected to last indefinitely in the CA site-wide model. This discrepancy requires further evaluation. However, this situation does not bear on the discussion of far-field dilution effects occurring with transport of contaminants released from the LLBG through the unconfined aquifer. The example provided above provides minimal dilution effects (because it provides the shortest 
HNF-3762, Rev. 0

path to a boundary) and maximum far-field dose, regardless the site-wide model selected. Also, either site-wide model predicts the same distribution from 218-E-12B (e.g., largely eastward flow).

\subsection{RADIONUCLIDE RELEASE AND TRANSPORT IN THE VADOSE ZONE}

In the previous LLBG PA annual review (Wood, 1998b), efforts at the Hanford Site to characterize contaminated vadose zone areas resulting from tank leaks were summarized. With regard to the disposal of low-level waste in the LLBG, relevance of the apparent enhanced mobility of ${ }^{137} \mathrm{Cs}$ in the soil column under the tank farm to potential radionuclide releases from the LLBG were evaluated. It was concluded that some combination of tank leak specific conditions were likely factors in the deep penetration of ${ }^{137} \mathrm{Cs}$ and ${ }^{99} \mathrm{Tc}$ (e.g., high $\mathrm{pH}$, high sodium, large leak volume). Because these conditions are and should continue to be absent from the LLBG environment, similar accelerated migration of ${ }^{137} \mathrm{Cs}$ or other radionuclides underneath the LLBG is not expected.

During fiscal year 1997, efforts were concentrated on tank leaks underlying the SX tank farm (Myers, et al, 1998). At this site, spectral gamma logging data showed that ${ }^{137} \mathrm{Cs}$ was present about 130 feet below the surface. Given the expected behavior of ${ }^{137} \mathrm{Cs}$ under normal conditions, the extent of vertical penetration was unexpected. Subsequently, an expert panel was convened to review the data and make recommendations for further work (DOE/RL 1997). As of the last annual review, additional boreholes were drilled (down to $130 \mathrm{ft}$ ), samples were taken and analyzed and more spectral gamma data were collected.

The fiscal year 1998 SX tank farm activities continue to support the basic premise provided in the previous annual review that more rapid and deeper penetration of radionuclide contaminants into the vadose zone underneath the tank farms is related to tank leak characteristics, primarily rapid release of large volumes of liquid and the chemistry of the tank liquor. Because these characteristics are not permitted at the LLBG, similar contaminant migration behavior from leached low-level solid waste is not feasible.

\subsection{COVER PERFORMANCE}

In the previous annual report, development and instrumentation of a prototype multilayer barrier was described. Results to date (Gee et al 1996) showed that even under aggressive artificial precipitation events, the combination of vegetative uptake of water, soil storage capacity, and evaporation were sufficient to prevent infiltration through the cover. A subsequent report 
HNF-3762, Rev. 0

(Ward, et al 1997) has been issued with additional data that support earlier conclusions. In all, data has been collected for three years. Some of the more significant observations are:

- Natural vegetation planted on the cover continues to flourish and increase in response to increased precipitation. The vegetation also appears to completely eliminate erosion, either by wind or water.

- Intermittent drainage was noted on the side slopes composed of gravel or basalt riprap. The authors indicated that some design changes might be required to eliminate these effects, but because of the limited spatial and temporal extent of the drainage, enhanced leaching of waste was not necessarily an expected consequence of drainage.

- Evidence of small animal activity has increased, but burrows are shallow (no more than $8 \mathrm{~cm}$ ) and have no impact on infiltration control.

These results support the PA assumption that a cover can be engineered that will limit infiltration to very small levels (easily less than the assumed minimum rate of $0.5 \mathrm{~cm} / \mathrm{yr}$ in the PAs), both in the interior of the cover and at the edges. These data also suggest that indigenous vegetation can be successfully established on an engineered cover and that a vegetated soil layer is by itself capable of controlling infiltration even for excessive precipitation conditions. Use of a less complex engineered cover for burial ground use is therefore plausible. The lack of erosion indicates that long-term cover stability is a feasible concept. Long-term stability supports two objectives of controlling infiltration and maintaining recognition of the facility to aid in the deterrence of inadvertent intruders for as long as 500 years postclosure.

Subsidence events in the LLBG have been routinely tracked for several years. When a subsidence event occurs, the general area of subsidence, the lateral extent and ciepth of hole are recorded. The subsidence areas are normally repaired by filling in the depression with soil. In cases of deep holes or reoccurring events in the same area, void space has been grouted.

The events to date suggest that two types of subsidences have occurred. The most common event is the formation of a shallow (up to a 1 - 2 feet deep), often wide spread ( 3 to $30 \mathrm{ft}$ in diameter) depression that is most likely the result of general settling of backfilled soils. The second, less common event, is a deep subsidence ( 4 to 6 feet) of variable diameter (up to 15 feet). This type of excavation is associated with large containers (e.g., wood boxes) with large internal void spaces. 
HNF-3762, Rev. 0

Of the two types of events, the second seems to be the most likely to cause a physical disruption of a cover. No information is yet available that can be used to evaluate the plausibility of this type of cover degradation. This can probably be addressed only by placement of a designed cover over a burial ground trench. In the meantime, subsidence events will continue to be monitored as to characteristics and frequency of occurrence.

\subsection{ENVIRONMENTAL MONITORING}

Monitoring of water and air for contaminants, both radiological and chemical, is an ongoing program that occurs sitewide. Also, in certain locations, vadose zone characterization is being conducted, primarily remediation sites and soil columns contaminated by tank leaks (see section 3.2). Groundwater monitoring wells and air sampling stations are present near the $200 \mathrm{West}$ and 200 East Area LLBG that are routinely monitored. Periodically, summary documents are issued that describe and interpret the collected information.

The latest summary of monitoring information (Dirkes and Hanf 1997) pulls together data collected through 1996. Numerous radioactive and chemical plumes are tracked by sampling and analyzing the monitoring wells. In the aquifer underlying the 200 West Area LLBG, there are no measured radionuclide plumes. Tritium, uranium, iodine and technetium plumes lie to the south and east in the unconfined aquifer. All plumes have plausible sources from various liquid discharge practices and there is no evidence or expectation that the 200 West Area LLBG are sources of current contamination. In the aquifer underlying the 200 East Area LLBG, iodine and tritium plumes are present whose source or sources are not clearly linked to a particular source. However, liquid discharge sites south of the LLBG are likely candidates. ${ }^{99} T C$ plume is present between $218-E-10$ and $218-E-12 B$ whose sources are likely cribs and possibly leaking tanks in the BX-BY tank farms.

The future impact of these current plumes on long-term dose effects were discussed in the CA. In the CA, estimated dose from these plumes in 2050 was a maximum of $6 \mathrm{mrem} / \mathrm{yr}$ assuming an all pathways agriculture scenario. The $\mathrm{CA}$ also predicts that any plumes emanating from the LLBG will not coincide with present plumes.

The latest summary of air contamination is also provided in the latest Hanford annual report (Dirkes and Hanf 1997). The prevailing winds for both burial grounds come from the northwest. Nearby monitoring stations for both burial grounds tracked beta and alpha radiation, tritium and iodine. All measured concentrations were orders of magnitude below Derived 
Concentration Guidelines (DOE 1990). This summary information cannot be directly applied to long-term conditions that are the subject of PA analyses, but they do provide some indication that future potential for air contamination is unlikely, because cover conditions will be more protective than they are today.

No vadose zone characterization efforts have been initiated in the burial grounds. $A$ review of potential monitoring applicable to the LLBG was completed in a letter report to DOE-RL (Wood 1998c). Several techniques were reviewed that have been used on site. It was concluded that the most promising approaches are sampling and analysis of water that has infiltrated through the disposal trenches and tracking of moisture through burial ground covers. However, none were recommended because (1) if releases are occurring, they are slow and sporadic, and therefore difficult to detect, (2) final closure conditions relevant to PA predictions have not been implemented, $(3)$ all available environmental indicators are consistent with expectations that contaminant releases from the LLBG are minimal, and (4) estimated environmental contamination due to LLBG waste disposals are very low (see Table 9 ).

\subsection{REFERENCES}

Cowan, S.P., 1996, Conditional Acceptance of the Hanford 200 West Area Burial Ground Performance Assessment, memorandum (EM-30) to C. Hansen, U.S. Department of Energy, Richland Operations Office, dated June 27, 1996, U.S. Department of Energy, Washington, D.C.

Dirkes, R.L., and R.W. Hanf (eds), 1997, Hanford Site Environmental Report for Calendar Year 1996, PNNL-11472, Pacific Northwest National Laboratory, Richland, Washington.

DOE, 1988, Radioactive Waste Management, DOE Order 5820.2A, U.S. Department of Energy, Washington, D.C.

DOE, 1990, Radiation Protection of the Public and Environment, DOE Order 5400.5, U.S. Department of Energy, Washington, D.C.

DOE, 1996a, Revised Interim Policy on Regulatory Structure for Low-Level Radioactive Waste Management and Disposal, U.S. Department of Energy, Washington, D.C.

DOE, 1996b, Maintenance of U.S. Department of Energy Low-Level Waste Performance Assessments, U.S. Department of Energy, Washington, D.C. 
HNF-3762, Rev. 0

DOE-RL, 1997, TWRS Vadose Zone Contamination issue Expert Pane/ Status Report, DOE/RL97-49, Revision 0, U.S. Department of Energy, Richland Operations Office, Richland, Washington.

Frei, M.W., 1997, Conditional Acceptance of the Hanford 200 East Area Burial Ground Performance Assessment, Memorandum (EM-30) to C. Hansen, U.S. Department of Energy, Richland Operations Office, dated June 30, 1997, U.S. Department of Energy, Washington, D.C.

Gee, G.W., A.L. Ward, B.G. Gilmore, S.O. Link, G.W. Dennis, and T.K. O'Neil, Hanford PrototypeBarrier Status Report FY 1996, PNNL-11367, Pacific Northwest National Laboratory, Richland, Washington.

Hanford Future Site Uses Working Group (HFSWG), 1992, The Future for Hanford: Uses and Cleanup, The Final Report of the Hanford Future Site Uses Working Group, Hanford Future Site Uses Working Group, Westinghouse Hanford Company, Richland, Washington.

Kincaid, C.T., M.P. Bergeron, C.R. Cole, M.D. Freshley, N.L. Hassig, V.G. Johnson, D.I. Kaplan, R.J. Serne, G.P. Streile, D.L. Strenge, P.D. Thorne, L.W. Vail, G.A. Whyatt, and S.K. Wurstner, 1998, Composite Analysis for the Low-Level Waste Disposal in the 200 Area Plateau of the Hanford Site, PNNL-11800, Pacific Northwest National Laboratory, Richland, Washington.

Lu, A.H., 1997, Unconfined Aquifer Contaminant Transport for Releases from Low-Level Solid Waste Burial Grounds in 200 East and West Areas. Letter Report from A. Lu to Fluor Daniel Northwest, Richland, Washington.

Lu, 1998, A Comparison of Contaminant Transport for Transient and Steady-State Simulations for Releases from Low-Level Solid Waste Burial Grounds. Letter Report from A. Lu to Fluor Daniel Northwest, Richland, Washington.

Myers, D.A., D.L. Parker, G. Gee, V.G. Johnson, G.V. Last, R.J. Serne, and D.J. Moak, 1998, Findings of the Extension of Borehole 41-09-39, 241-SX Tank Farm, HNF-2855, Rev. 0, Lockheed Martin Hanford Corporation, Richland, Washington.

Ward, A.L., G.W. Gee and S.O. Link, 1997, Hanford Prototype-Barrier Status Report: FY 1997, PNNL-11789, Pacific Northwest National Laboratory, Richland, Washington. 
Wood M.I, R. Khaleel, P.D. Rittmann, A.H. Lu, S.H. Finfrock, R.J. Serve, K.J. Cantrell, and T.H. De Lorenzo, 1995, Performance Assessment for the Disposal of Low-Level Waste in the 200 West Area Burial Grounds, WHC-EP-0645, Westinghouse Hanford Company, Richland, Washington.

Wood, M.I., 1996, Addendum to the Performance Assessment Analysis for Low-Level Waste Disposal in the 200 West Area Active Burial Grounds, HNF-SD-WM-TI-798, Rev, 0, Rust Federal Services of Hanford, Inc., Richland, Washington.

Wood M.I., R. Khaleel, P.D. Rittmann, A.H. Lu, S.H. Finfrock, T.H. De Lorenzo, and D.Y. Garbrick, 1996, Performance Assessment for the Disposal of Low-Level Waste in the 200 East Area Burial Grounds, WHC-SD-WM-TI-730, Westinghouse Hanford Company, Richland, Washington.

Wood, M. I., 1997, Program Plan for Maintenance of Hanford Burial Ground Performance Assessment (PA) Analyses. Letter Report from Waste Management Federal Services of Hanford, Inc. to Department of Energy-Richland Office, Richland, Washington.

Wood, M.I., 1998a, Addendum to the Performance Assessment Analysis for Low-Level Waste Disposal in the 200 East Area Active Burial Grounds, HNF-2005, Rev. 0, Waste Management Federal Services of Hanford, Inc., Richland, Washington.

Wood, M.l., 1998b, 1996-1997 Review of the 200 West and 200 East Area Performance Assessments, HNF-1561, Rev. 0, Waste Management Federal Services of Hanford, Inc., Richland, Washington.

Wood, M.I., 1998c, 1998, Evaluation of Monitoring Approaches for the Hanford Site Low-Level Burial Grounds, Letter Report from Waste Management Federal Services of Hanford, Inc. to Department of Energy-Richland Office, Richland, Washington. 
Figure 1. Low-Level Waste Burial Ground Locations in the 200 West Area (Wood et al, 1995)

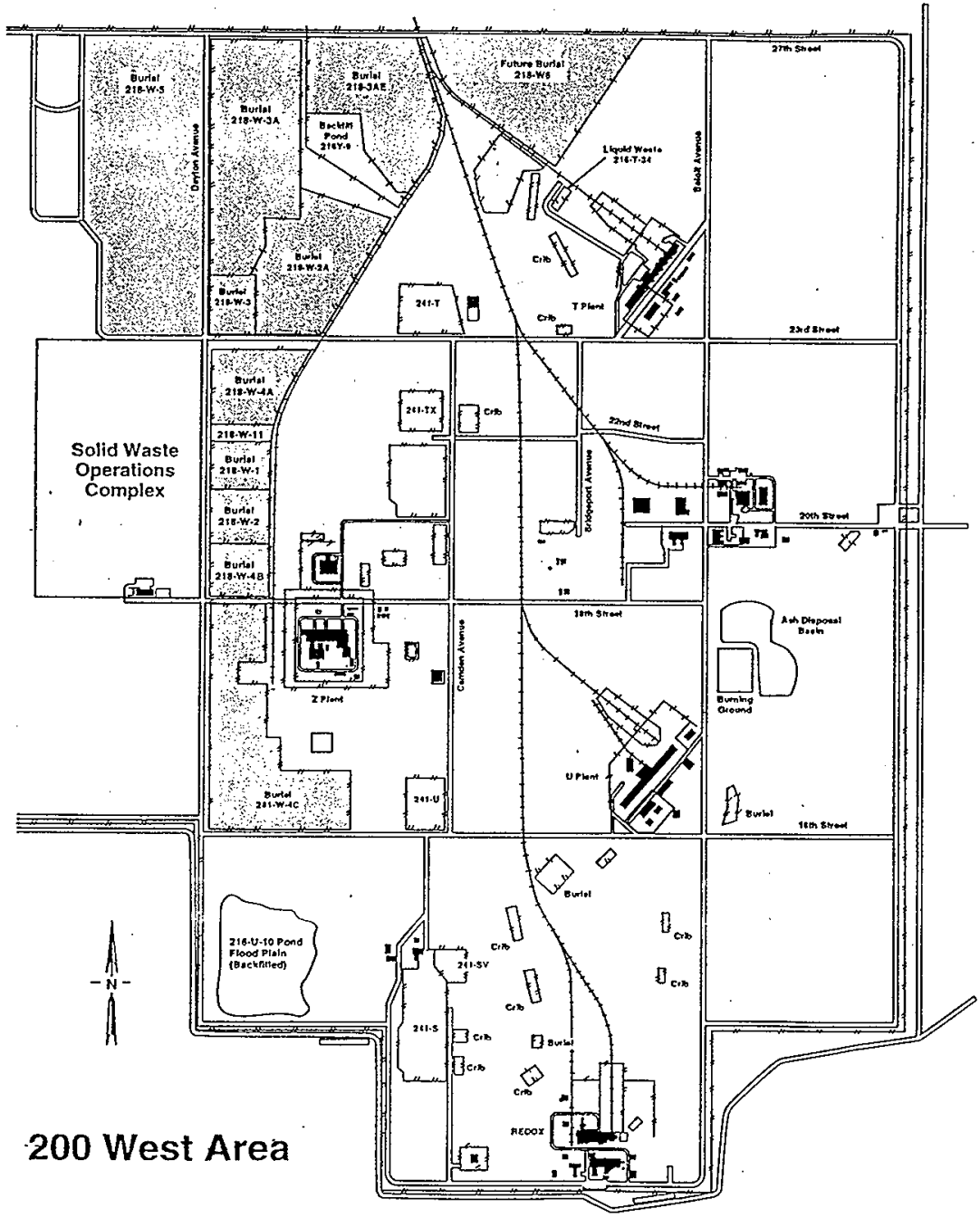


Figure 2. Low-Level Waste Burial Ground Locations in the 200 East Area (Wood et al, 1996)

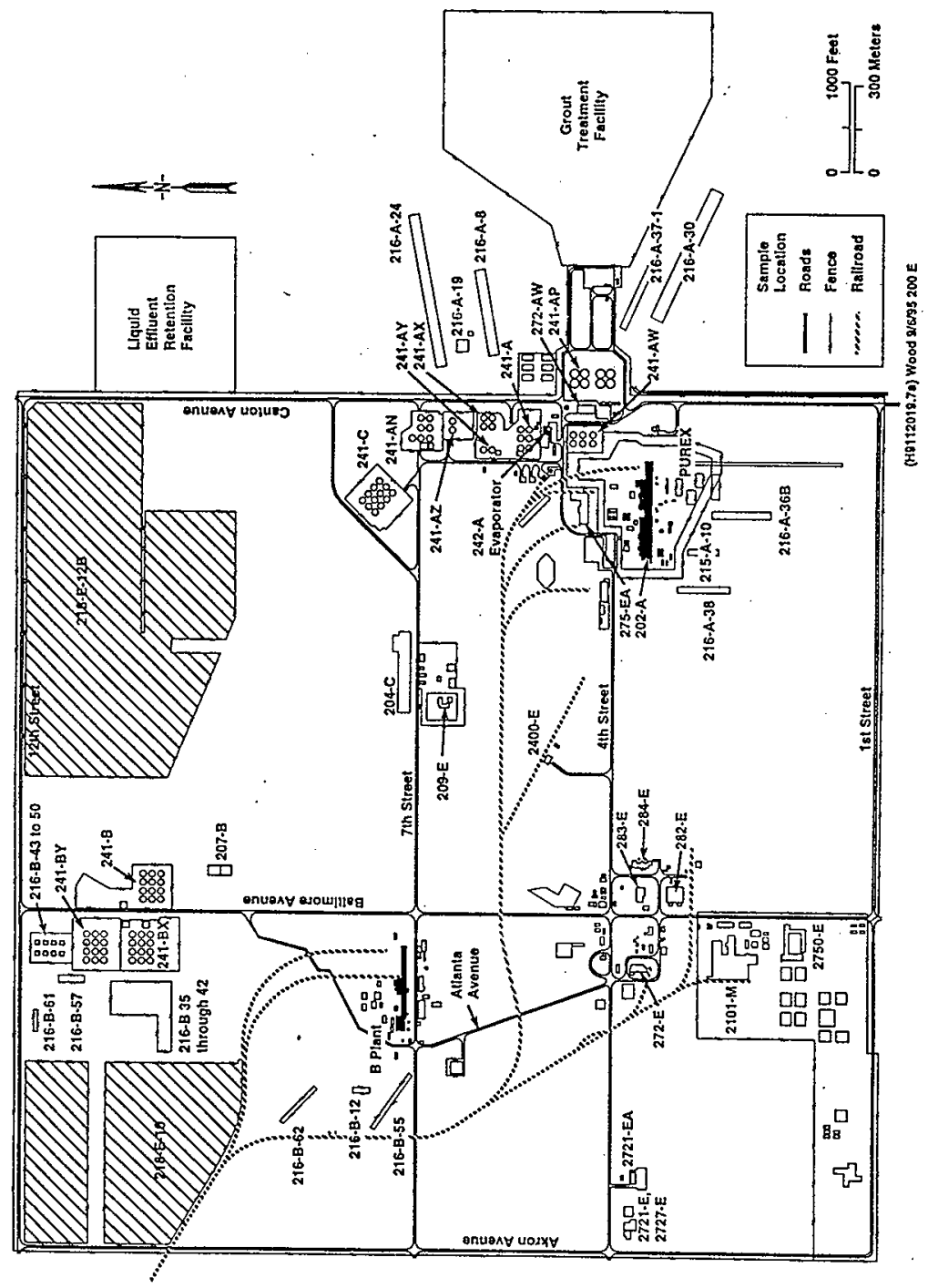


Figure 3. Location of Downstream Wells from the LLBG and Major Unconfined Aquifer Flow Paths Assuming Steady State Postclosure Conditions (Lu 1998)

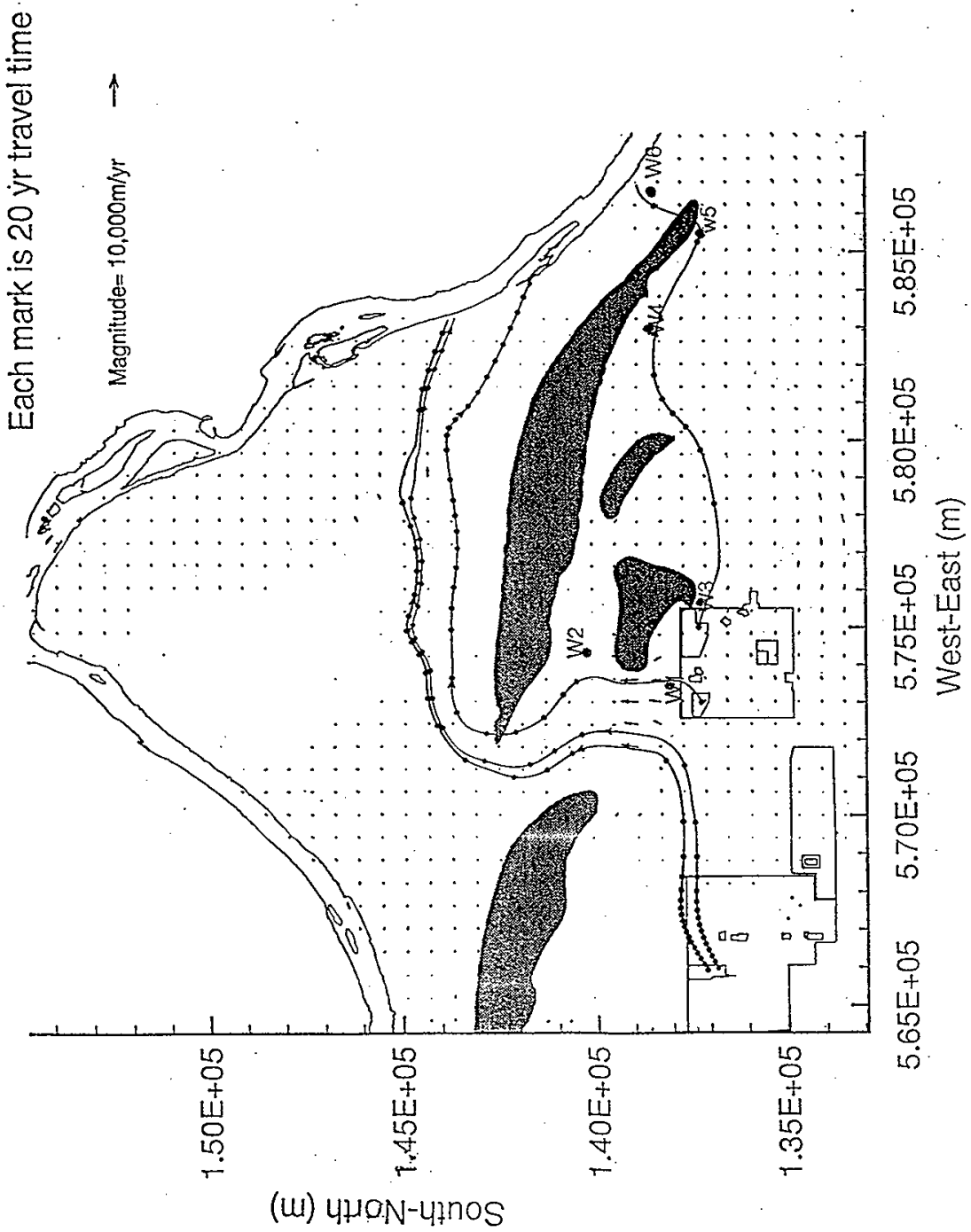


Figure 4. Concentration Contours in the Unconfined Aquifer in 2996 from Radionuclide Release Initiated in 1996 from the 200 West Area (Lu 1998)

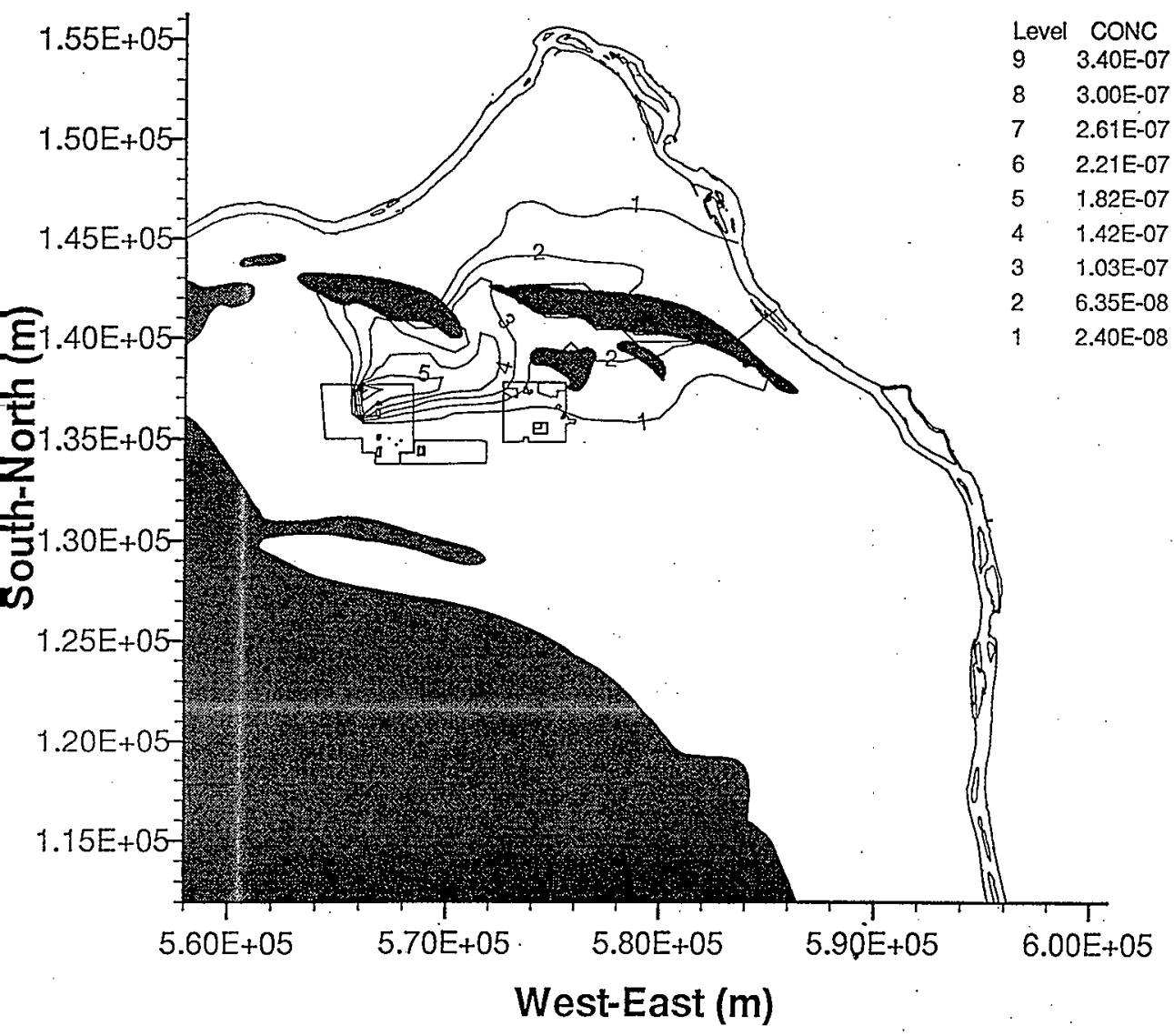


HNF-3762, Rev. 0

Figure 5. Radionuclides Concentrations Over Time at Wells $W 1$ and $W 2$ from Radionuclide Release Initiated in 1996 from the 200 West Area (Lu 1998)

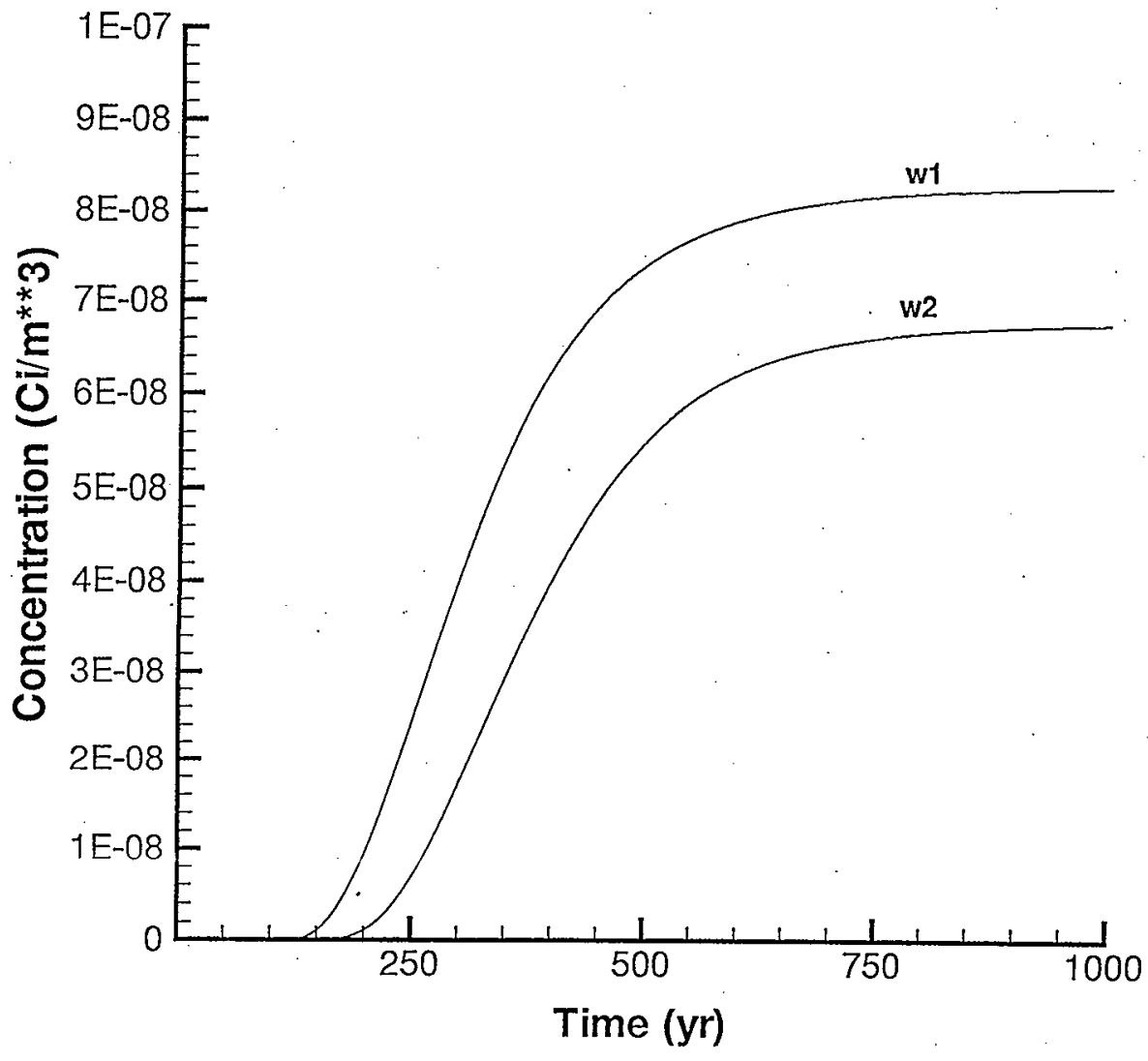


Figure 6. Radionuclides Concentrations Over Time at Wells W3 through W6 from Radionuclide Release from the 200 West Area Initiated in 1996 (Lu 1998)

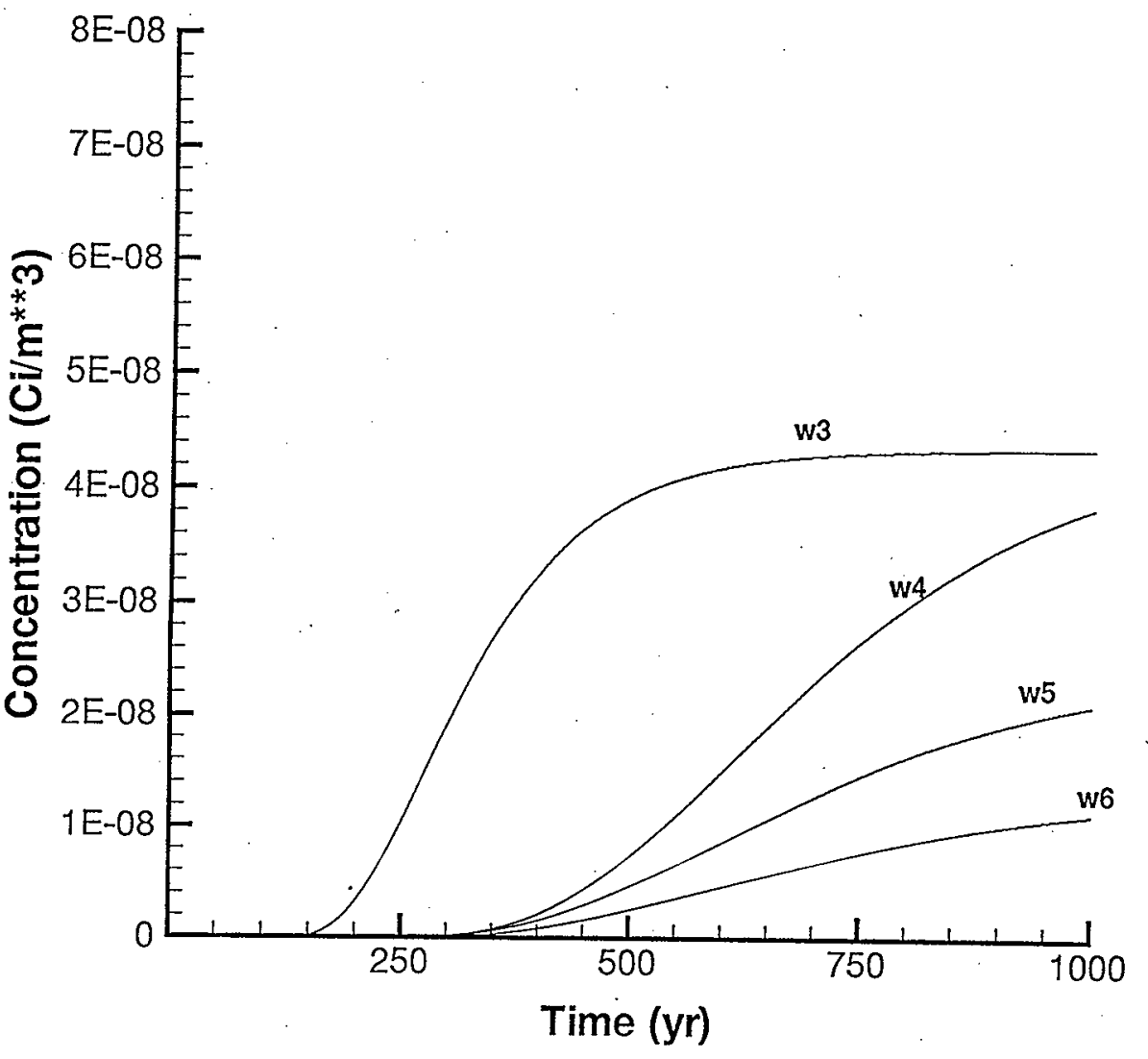


HNF-3762, Rev. 0

Table 1. Summary of Waste Volumes and Activities Disposed By Burial Ground 8/1/97 through 7/31/98

\begin{tabular}{|c|c|c|c|c|c|c|}
\hline \multirow[b]{2}{*}{ Burial Ground } & \multicolumn{4}{|c|}{ West Area } & \multicolumn{2}{|c|}{ East Area } \\
\hline & 218-W3A & 218-W3AE & 218-W4C & 218-W5 & 218-E10 & 218-E12B* \\
\hline Disposed Volume $\left(m^{\wedge} 3\right)$ & $1.65 \mathrm{E}+02$ & $5.39 E+02$ & $1.09 E+02$ & $2.73 E+03$ & $2.39 \mathrm{E}+02$ & $2.94 \mathrm{E}+\mathrm{O} 2$ \\
\hline Radionuclide & \multicolumn{6}{|c|}{ Total Inventory (Ci) } \\
\hline $\mathrm{U}-232$ & \multirow{2}{*}{ B. } & $7.67 \mathrm{E}-04$ & 3.78E-05 & 1.70E-04 & \multirow{2}{*}{ 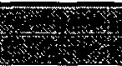 } & \multirow[b]{2}{*}{ 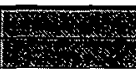 } \\
\hline U-233 & & $2.10 \mathrm{E}-02$ & $6.31 E-05$ & $4.80 \mathrm{E}-05$ & & \\
\hline U-234 & $1.78 E-05$ & $7.51 \mathrm{E}+00$ & 2.32E-03 & $4.70 E-03$ & $1.10 \mathrm{E}-07$ & $1.38 \mathrm{E}-08$ \\
\hline $\mathrm{U}-235$ & $8.89 E-08$ & $1.10 \mathrm{E}-01$ & $5.28 \mathrm{E}-05$ & $6.90 \mathrm{E}-04$ & $3.40 E-05$ & $3 . \overline{68 \mathrm{E}}-06$ \\
\hline $\mathrm{U}-236$ & $1.47 \mathrm{E}-06$ & 2.30E-04 & $1.78 \mathrm{E}-09$ & $3.50 \mathrm{E}-04$ & Now & ST) \\
\hline $\mathrm{U}-238$ & 3.77E-06 & $7.91 \mathrm{E}+00$ & $2.27 \mathrm{E}-03$ & 1.13E-02 & $5.29 \mathrm{E}-04$ & 5.62E 05 \\
\hline Total U & 2.31E-05 & $1.56 \mathrm{E}+01$ & $4.74 \mathrm{E}-03$ & $1.73 \mathrm{E}-02$ & $5.63 E-04$ & 5.99E-05 \\
\hline $\mathrm{H}-3$ & \multirow{6}{*}{$\begin{array}{l}3 \\
4 \\
4 \\
4\end{array}$} & $1.05 E-01$ & $6.61 \mathrm{E}-02$ & $4.15 \mathrm{E}+03$ & \multirow{7}{*}{ (5) } & \multirow{7}{*}{ 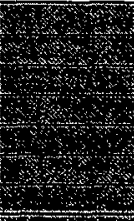 } \\
\hline $\mathrm{C}-14$ & & $3.74 \mathrm{E}-01$ & $2.90 \bar{E}-04$ & 1.57E-01 & & \\
\hline $\mathrm{Cl}-36$ & & (1) & $6.00 E-06$ & $2.37 E-08$ & & \\
\hline Se-79 & & 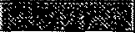 & W & & & \\
\hline Tc-99 & & $1.05 \mathrm{E}-01$ & $2.08 \mathrm{E}-03$ & $1.92 E-02$ & & \\
\hline $1-129$ & & 1.50E-05 & $3.08 \mathrm{E}-05$ & W & & \\
\hline Np-237 & $7.60 \mathrm{E}-04$ & $5.20 \mathrm{E}-03$ & $1.30 \mathrm{E}-04$ & $6.00 \mathrm{E}-04$ & & \\
\hline Total Mobile Isotopes & $7.60 \mathrm{E}-04$ & $5.89 \mathrm{E}-01$ & $6.86 \mathrm{E}-02$ & $4.15 \mathrm{E}+03$ & 4 & $\begin{array}{ll}4 \\
4\end{array}$ \\
\hline Cs-137 & $2.48 \mathrm{E}+00$ & $1.32 \mathrm{E}+03$ & $2.98 \mathrm{E}-02$ & $3.70 \mathrm{E}-01$ & $9.80 \mathrm{E}-04$ & $6.40 \mathrm{E}-04$ \\
\hline Sr-90 & $2.26 \mathrm{E}+00$ & $2.68 \mathrm{E}+03$ & $2.85 \mathrm{E}-02$ & $3.23 \mathrm{E}-01$ & 5.44E-03 & $2.30 \mathrm{E}-04$ \\
\hline Others & $4.07 \mathrm{E}+00$ & $5.93 \mathrm{E}+00$ & $2.09 \mathrm{E}-01$ & $4.10 \mathrm{E}+00$ & $6.00 \mathrm{E}-04$ & $1.00 \mathrm{E}-04$ \\
\hline Total (Cs+Sr+Others) & $8.81 E+00$ & $4.00 E+03$ & 2.67E-01 & $4.79 E+00$ & $7.02 E-03$ & $9.70 E-04$ \\
\hline Grand Total & $8.81 E+00$ & $4.02 E+03$ & 3.41E-01 & $4.15 E+03$ & 7.58E-03 & $1.03 \mathrm{E}-03$ \\
\hline
\end{tabular}

* Reactor compartment inventory is not included. This is provided separately in Table 4. 
Table 2. Uranium Waste Disposed from $8 / 1 / 97$ through $7 / 31 / 98$

\begin{tabular}{|c|c|c|c|c|c|c|c|c|}
\hline \multicolumn{9}{|c|}{ Mass $(\mathrm{g})$ of Disposed Uranium Waste } \\
\hline $\begin{array}{l}\text { Burial } \\
\text { Ground }\end{array}$ & Trench & $U-232$ & $\mathrm{U}-233$ & U-234 & $\mathrm{U}-235$ & $U-236$ & $\mathrm{U}-238$ & Total U \\
\hline \multicolumn{9}{|c|}{ EAST AREA } \\
\hline $\mathrm{E} 10$ & 9 & S. & (X) & 1.76E-05 & $1.57 E+01$ & 28 & $1.57 E+03$ & $1.59 \bar{E}+03$ \\
\hline $\mathrm{E} 12 \mathrm{~B}$ & 42 & S. & KX) & $2.20 \mathrm{E}-06$ & $1.70 \mathrm{E}+00$ & -8 & $1.67 \mathrm{E}+02$ & $1.69 \mathrm{E}+02$ \\
\hline \multicolumn{9}{|c|}{ WEST AREA } \\
\hline W3A & $49(\mathrm{HIC})$ & Fos & (2) & $2.85 \mathrm{E}-03$ & $4.11 \mathrm{E}-02$ & $2.30 E-02$ & $1.12 \mathrm{E}+01$ & $1.13 E+01$ \\
\hline \multirow{3}{*}{ W3AE } & $8(\mathrm{HIC})$ & 1.29E-05 & $2.32 E+00$ & $1.20 \mathrm{E}+03$ & $5.16 \mathrm{E}+04$ & 7.73E-05 & $2.35 \mathrm{E}+07$ & $2.36 \mathrm{E}+07$ \\
\hline & $8(\mathrm{no} \mathrm{H})$ & 2.36E-05 & $1.34 \mathrm{E}-02$ & $2.16 \mathrm{E}-01$ & $2.05 \mathrm{E}+02$ & $3.60 \mathrm{E}+00$ & $2.79 E+04$ & $2.81 \mathrm{E}+04$ \\
\hline & 13 & 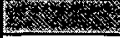 & 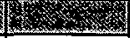 & 5 & $1.70 E+00$ & Wh & 1.67E+02 & $1.69 \mathrm{E}+02$ \\
\hline W4C & 33 & 1.80E-06 & $6.58 \mathrm{E}-03$ & $3.70 E-01$ & $2.44 \mathrm{E}+01$ & $2.79 \mathrm{E}-05$ & $6.76 \mathrm{E}+03$ & $6.79 \mathrm{E}+03$ \\
\hline \multirow[t]{2}{*}{ W5 } & 29 & 8.00E-06 & $5.15 \mathrm{E}-03$ & 7.47E-01 & $3.19 E+02$ & $5.52 E+00$ & $3.35 E+04$ & $3.38 \mathrm{E}+04$ \\
\hline & 33 & 4 & 45 & 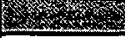 & 1.36E-02 & $2.11 \mathrm{E}+00$ & 4 & $2.12 \mathrm{E}+00$ \\
\hline \multicolumn{2}{|c|}{ West Total (no HIC) } & $3.34 \mathrm{E}-05$ & $2.51 \mathrm{E}-02$ & $1.33 E+00$ & $5.50 E+02$ & $1.12 E+01$ & $6.83 E+04$ & $6.88 \mathrm{E}+04$ \\
\hline \multicolumn{2}{|c|}{ West Total (HIC) } & 1.29E-05 & $2.32 \mathrm{E}+00$ & $1.20 E+03$ & $5.16 \mathrm{E}+04$ & 2.31E-02 & $2.35 E+07$ & $2.36 \mathrm{E}+07$ \\
\hline \multicolumn{9}{|c|}{ Activity (Ci) of Disposed Uranium Waste } \\
\hline $\begin{array}{l}\text { Burial } \\
\text { Ground }\end{array}$ & Trench & $\mathrm{U}-232$ & $U-233$ & $U-234$ & U-235 & U-236 & U-238 & Total U \\
\hline \multicolumn{9}{|c|}{ EAST AREA } \\
\hline E10 & 9 & W6. & (X) & $1.10 \varepsilon-07$ & 3.40E-05 & & 5.29E-04 & 5.63E-04 \\
\hline E12B & 42 & & 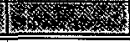 & $1.38 \mathrm{E}-08$ & $3.68 \mathrm{E}-06$ & & $5.62 E-05$ & $5.99 \mathrm{E}-05$ \\
\hline \multicolumn{9}{|c|}{ WEST AREA } \\
\hline W3A & $49(\mathrm{HIC})$ & 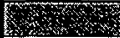 & 26 & $1.78 \mathrm{E}-05$ & 8.89E-08 & 1.47E-06 & 3.77E-06 & 2.31E-05 \\
\hline \multirow{3}{*}{ W3AE } & $8(\mathrm{HIC})$ & $2.71 \mathrm{E}-04$ & 2.22E-02 & $7.50 \mathrm{E}+00$ & $1.12 E-01$ & 4.95E-09 & $7.91 \mathrm{E}+00$ & $1.55 \mathrm{E}+01$ \\
\hline & $8(\mathrm{noH})$ & $4.96 \mathrm{E}-04$ & $1.29 \mathrm{E}-04$ & 1.35E-03 & $4.44 \mathrm{E}-04$ & $2.30 \mathrm{E}-04$ & 9.37E-03 & 1.20E-02 \\
\hline & 13 & $V^{2}$ & 18 & 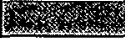 & $3.68 \mathrm{E}-06$ & - & 5.62E-05 & $5.98 \mathrm{E}-05$ \\
\hline W4C & 33 & 3.78E-05 & $6.31 \mathrm{E}-05$ & 2.32E-03 & $5.28 E-05$ & $1.78 \mathrm{E}-09$ & 2.27E-03 & $4.74 \mathrm{E}-03$ \\
\hline \multirow[t]{2}{*}{ W5 } & 29 & $1.68 \mathrm{E}-04$ & 4.94E-05 & $4.67 \mathrm{E}-03$ & $6.89 \mathrm{E}-04$ & $3.54 \mathrm{E}-04$ & 1.13E-02 & $1.72 \mathrm{E}-02$ \\
\hline & 33 & 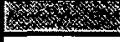 & 25 & 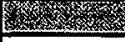 & $2.94 \mathrm{E}-08$ & $1.35 \mathrm{E}-04$ & S & 1.35E-04 \\
\hline \multicolumn{2}{|c|}{ West Total (no HIC) } & 7.01E-04 & 2.41E-04 & 8.33E-03 & 1.19E-03 & 7.19E-04 & 2.30E-02 & $3.41 \mathrm{E}-02$ \\
\hline \multicolumn{2}{|c|}{ West Total (HIC) } & 2.71E-04 & 2.22E-02 & $7.50 \mathrm{E}+00$ & 1.12E-01 & $1.48 E-06$ & $7.91 E+00$ & $1.55 \mathrm{E}+01$ \\
\hline
\end{tabular}


HNF-3762, Rev. 0

Table 3. Mobile Radionuclides (Ci) disposed from $8 / 1 / 97$ through $7 / 31 / 98$

\begin{tabular}{|c|c|c|c|c|c|c|c|c|}
\hline $\begin{array}{l}\text { Burial } \\
\text { Ground }\end{array}$ & Trench & $\mathrm{H}-3$ & C-14 & $\mathrm{Cl}-36$ & $\mathrm{Se}-79$ & Tc-99 & $1-129$ & $\mathrm{~Np}-237$ \\
\hline \multicolumn{9}{|c|}{ EAST AREA } \\
\hline E10 & 9 & W & & S. & 64 & 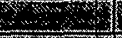 & $6+3$ & $1.00 \mathrm{E}-04$ \\
\hline E12B & 42 & $6 \mathrm{n}-\mathrm{s}$ & 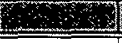 & $W_{1}$ & 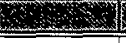 & 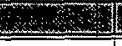 & $8 \quad . \quad 3$ & . \\
\hline \multicolumn{9}{|c|}{ WEST AREA } \\
\hline W3A & 49 (HIC) & $8 \times$ & 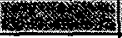 & 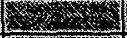 & 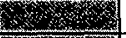 & 3.30E-04 & 8. & $7.60 \mathrm{E}-04$ \\
\hline \multirow{4}{*}{ W3AE } & $8(\mathrm{HIC})$ & 8.60E-02 & $3.19 \mathrm{E}-02$ & W & 869 & $1.04 \mathrm{E}-01$ & - & $5.30 \mathrm{E}-03$ \\
\hline & 8 (no HIC) & 1.90E-02 & $1.56 \mathrm{E}-03$ & $4, k \%$ & Wh & $1.00 \mathrm{E}-03$ & $1.50 \mathrm{E}-05$ & 1.46E-05 \\
\hline & 13 & & & & & & & $2.10 \mathrm{E}-04$ \\
\hline & $16(\mathrm{HIC})$ & - & & H & & W & & $=$ \\
\hline W4C & 33 & 6.60E-02 & $2.90 E-04$ & $6.00 \mathrm{E}-06$ & 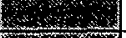 & $2.08 \mathrm{E}-03$ & $3.08 \mathrm{E}-05$ & $1.30 \mathrm{E}-04$ \\
\hline \multirow[b]{2}{*}{ W5 } & $29^{*}$ & $4.15 \mathrm{E}+03$ & $1.57 \mathrm{E}-01$ & $6.26 \mathrm{E}-07$ & s. & $1.92 \mathrm{E}-02$ & & $6.07 \mathrm{E}-04$ \\
\hline & 33 & 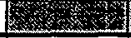 & 5 & (1) & $\delta_{3}$ & L. & 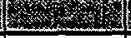 & 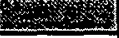 \\
\hline \multicolumn{2}{|c|}{ West Total } & 4.15E+03 & $1.91 \mathrm{E}-01$ & $6.63 E-06$ & $0.00 E+00$ & $1.26 \mathrm{E}-01$ & 4.58E-05 & $7.02 E-03$ \\
\hline \multicolumn{9}{|c|}{$\begin{array}{l}\text { - Tritium waste is primarily tritiated water sorbed onto molecular sieves or silica gel to delay and reduce } \\
\text { tritium release. Neglible transport to the water table from these wastes is expected. }\end{array}$} \\
\hline
\end{tabular}


HNF-3762, Rev. 0

Table 4. Reactor Compartment Inventory (Ci) Disposed from 8/1/97 to $7 / 31 / 98$

\begin{tabular}{|c|c|}
\hline Radionuclides & Inventory (Ci) \\
\hline $\mathrm{C}-14$ & $2.06 \mathrm{E}+01$ \\
\hline Am-241 & $3.30 \mathrm{E}-02$ \\
\hline $\mathrm{Nb}-94$ & $5.85 \mathrm{E}+04$ \\
\hline $\mathrm{Ni}-63$ & $1.40 \mathrm{E}+05$ \\
\hline $\mathrm{Co}-60$ & $2.07 \mathrm{E}+04$ \\
\hline $\mathrm{Cs}-137$ & $2.35 \mathrm{E}-01$ \\
\hline $\mathrm{Pu}-241$ & $2.23 \mathrm{E}+00$ \\
\hline $\mathrm{Sr}-90$ & $2.38 \mathrm{E}-01$ \\
\hline
\end{tabular}

Table 5. Projected Low-Level and Mixed Low-Level Waste Inventory To Be Disposed in the LLBG (1998 to Closure)

\begin{tabular}{|c|c|}
\hline Radionuclides & Inventory (Ci) \\
\hline H-3 & $3.83 \mathrm{E}+05$ \\
\hline $\mathrm{C}-14^{*}$ & $6.14 \mathrm{E}+01$ \\
\hline $\mathrm{Cl}-36$ & $4.99 \mathrm{E}-05$ \\
\hline Co-60 & $4.23 \mathrm{E}+05$ \\
\hline Se-79 & $5.45 \mathrm{E}-04$ \\
\hline Sr-90 & $3.86 \mathrm{E}+07$ \\
\hline Tc-99 & $1.58 \mathrm{E}+01$ \\
\hline I-129 & $2.65 \mathrm{E}+00$ \\
\hline Cs-137 & $3.84 \mathrm{E}+07$ \\
\hline Np-237 & $1.50 \mathrm{E}+00$ \\
\hline Pu-241 & $1.09 \mathrm{E}+03$ \\
\hline Pu & $2.69 \mathrm{E}+03$ \\
\hline Am & $2.59 \mathrm{E}+03$ \\
\hline U-233 & $1.84 \mathrm{E}+00$ \\
\hline$U-234$ & $3.18 \mathrm{E}-01$ \\
\hline$U-235$ & $1.43 \mathrm{E}+00$ \\
\hline U-238 & $1.03 \mathrm{E}+00$ \\
\hline U Total & $4.61 \mathrm{E}+00$ \\
\hline Other & $1.04 \mathrm{E}+02$ \\
\hline Total & $7.78 \mathrm{E}+07$ \\
\hline \hline
\end{tabular}

*53.48 $\mathrm{Ci}$ are present in activated metal and $7.92 \mathrm{Ci}$ are associated with unconsolidated waste 
HNF-3762, Rev. 0

Table 6. Groundwater Drinking Water Dose (mrem/yr) for Category 3 Conditions by Burial Ground

\begin{tabular}{|c|c|c|c|c|}
\hline \multirow[t]{2}{*}{ Burial Ground } & \multirow[t]{2}{*}{ Uranium dose } & \multicolumn{2}{|c|}{ Mobile Radionuclide Dose } & \multirow[t]{2}{*}{ Total Dose } \\
\hline & & reported & estimated & \\
\hline & & \multicolumn{2}{|c|}{$9 / 27 / 88-7 / 31 / 97$} & \\
\hline West Area & 1.33E-01 & $2.26 \mathrm{E}-02$ & 4.71E-02 & 2.02E-01 \\
\hline $\mathrm{E} 10$ & 3.87E-05 & $0.00 \mathrm{E}+00$ & $5.58 \mathrm{E}-03$ & $5.62 \mathrm{E}-03$ \\
\hline \multirow[t]{2}{*}{$\mathrm{E} 12 \mathrm{~B}$} & $1.50 \mathrm{E}-03$ & $9.40 \mathrm{E}-11$ & $5.19 \mathrm{E}-04$ & $2.02 \mathrm{E}-03$ \\
\hline & & \multicolumn{2}{|c|}{$8 / 1 / 97-7 / 31 / 98$} & \\
\hline West Area & 2.37E-03 & 7.38E-04 & $1.91 \mathrm{E}-03$ & $5.01 \mathrm{E}-03$ \\
\hline E10 & 2.63E-04 & $0.00 E+00$ & $2.01 \mathrm{E}-08$ & $2.63 \mathrm{E}-04$ \\
\hline \multirow[t]{2}{*}{$\mathrm{E} 12 \mathrm{~B}$} & $3.80 \mathrm{E}-06$ & $0.00 \mathrm{E}+00$ & $1.32 \mathrm{E}-08$ & $3.81 \mathrm{E}-06$ \\
\hline & & \multicolumn{2}{|c|}{ Current Inventory Total Dose } & \\
\hline West Area & $1.35 \mathrm{E}-01$ & $2.33 \mathrm{E}-02$ & $4.90 \mathrm{E}-02$ & 2.07E-01 \\
\hline E10 & $3.01 \mathrm{E}-04$ & $0.00 E+00$ & $5.58 \mathrm{E}-03$ & $5.88 \mathrm{E}-03$ \\
\hline \multirow[t]{2}{*}{$E 12 B$} & 1.50E-03 & $9.40 \mathrm{E}-11$ & $5.19 \mathrm{E}-04$ & $2.02 \mathrm{E}-03$ \\
\hline & & \multicolumn{2}{|c|}{ Projected Inventory Dose ${ }^{\star}$} & \\
\hline \multirow[t]{2}{*}{ West Area } & $5.00 \mathrm{E}-05$ & & $4.80 \mathrm{E}-01$ & 4.80E-01 \\
\hline & & \multicolumn{2}{|c|}{ Current + Projected Dose } & \\
\hline West Area & $1.35 \mathrm{E}-01$ & 2.33E-02 & 5.29E-01 & $6.88 \mathrm{E}-01$ \\
\hline E10 & $3.01 \mathrm{E}-04$ & $0.00 \mathrm{E}+00$ & $5.58 \mathrm{E}-03$ & $5.88 \mathrm{E}-03$ \\
\hline $\mathrm{E} 12 \mathrm{~B}$ & $1.50 \mathrm{E}-03$ & $9.40 \mathrm{E}-11$ & 5.19E-04 & $2.02 \mathrm{E}-03$ \\
\hline
\end{tabular}

* This projected dose assumes all future waste inventory is disposed in West Area Burial Grounds under Category 3 conditions with no waste form performance except placement of future uranium in concrete containers and some unspecified waste form for projected $1-129$ containing waste. The primary mobile radionuclide providing dose in this estimate is $1-129$ with a dose of $0.32 \mathrm{mrem} / \mathrm{yr}$. 
Table 7. Category 3 Dose Estimates (mrem/yr) For Disposed Inventory

\begin{tabular}{|c|c|c|c|c|c|c|c|c|}
\hline \multirow{2}{*}{$\begin{array}{l}\text { Burial } \\
\text { Grouind }\end{array}$} & \multirow[t]{2}{*}{ Trench } & \multicolumn{2}{|c|}{ Uranium Dose } & \multicolumn{4}{|c|}{ Mobile Radionuclide Dose } & \multirow{2}{*}{$\begin{array}{l}\text { Total } \\
\text { Dose }\end{array}$} \\
\hline & & $\begin{array}{l}9 / 27 / 88- \\
07 / 31 / 97\end{array}$ & $\begin{array}{l}8 / 1 / 97- \\
7 / 31 / 98\end{array}$ & $\begin{array}{l}9 / 27 / 88- \\
07 / 31 / 96\end{array}$ & $\begin{array}{c}\text { Key } \\
\text { Nuclides }\end{array}$ & $\begin{array}{l}8 / 1 / 97- \\
7 / 31 / 98\end{array}$ & $\begin{array}{c}\text { Key } \\
\text { Nuclides }\end{array}$ & \\
\hline \multicolumn{9}{|c|}{ EAST AREA } \\
\hline E10 & 9 & 3.87E-05 & 2.63E-04 & s. & & & & 3.01E-04 \\
\hline $\mathrm{E} 12 \mathrm{~B}$ & $32.38,42,48,53$ & $1.50 \mathrm{E}-03$ & $3.80 E-06$ & $9.40 \mathrm{E}-11$ & $\mathrm{C}$ & & & $1.50 \mathrm{E}-03$ \\
\hline \multicolumn{9}{|c|}{ WEST AREA } \\
\hline \multirow{5}{*}{ W-3A } & $19^{*}$ & $3.39 \mathrm{E}+00$ & & $4.50 \mathrm{E}-02$ & $\mathrm{C}$ & & & $3.44 E+00$ \\
\hline & $3 S^{*}$ & $1.50 \mathrm{E}-01$ & & $5.60 \mathrm{E}-04$ & Tc & 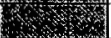 & & $1.51 \mathrm{E}-01$ \\
\hline & $46^{*}$ & $2.20 E-01$ & & $5.30 \mathrm{E}-14$ & $\mathrm{C}$ & & & $2.20 \mathrm{E}-01$ \\
\hline & 49 & $5.00 E-01$ & & 4.27E-02 & Tc & $1.60 \mathrm{E}-04$ & $\mathrm{TC}$ & 5.43E-01 \\
\hline & $6 S^{*}$ & $1.50 \mathrm{E}-03$ & 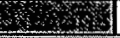 & $2.20 \mathrm{E}-04$ & $\mathrm{I}$ & & & $1.72 \mathrm{E}-03$ \\
\hline \multirow{5}{*}{ W-3AE } & $3^{*}$ & $2.23 \mathrm{E}-02$ & 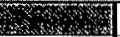 & 2.90E-03 & Tc & & & $2.52 \mathrm{E}-02$ \\
\hline & $8^{\star \star}$ & $7.20 \mathrm{E}-02$ & 2.85E-02 & $1.20 \mathrm{E}-01$ & $T c, 0$ & $2.50 \mathrm{E}-02$ & To & 2.46E-01 \\
\hline & 13 & $8.00 E-04$ & & 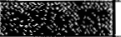 & & & & $8.00 \mathrm{E}-04$ \\
\hline & 16 & $2.61 \mathrm{E}+00$ & S. & $1.73 \mathrm{E}-02$ & Tc & & & $2.62 E+00$ \\
\hline & 26 & $1.10 \mathrm{E}+00$ & $5 \times$ & $1.69 \mathrm{E}-02$ & Tc & -4 & & $1.12 E+00$ \\
\hline \multirow{5}{*}{$W-4 C$} & $14^{\star \star}$ & $5.26 \mathrm{E}-01$ & s & $1.50 \mathrm{E}-01$ & $\overline{\mathrm{C}, \mathrm{Tc}}$ & $8 \mathrm{~s}, \mathrm{~s}$ & & $6.76 \mathrm{E}-01$ \\
\hline & $33^{\star}$ & $4.30 \mathrm{E}-02$ & 1.33E-02 & $1.02 E-02$ & C, TC, 1 & $5.64 E-03$ & $\mathrm{Tc}$ & $7.21 \mathrm{E}-02$ \\
\hline & $48^{*}$ & $7.00 \mathrm{E}-04$ & & $1.10 \mathrm{E}-09$ & Tc & & & 7.00E-04 \\
\hline & $53^{*}$ & $2.00 \mathrm{E}-03$ & & $7.80 \mathrm{E}-04$ & TC & & & $2.78 E-03$ \\
\hline & $\mathrm{NC}^{*}$ & $1.10 \mathrm{E}-02$ & 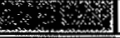 & $6.95 \mathrm{E}-01$ & $\mathrm{C}$ & S & & $7.06 \mathrm{E}-01$ \\
\hline \multirow{9}{*}{$W-5$} & $3^{\star}$ & 1.00E-04 & & $5.40 \mathrm{E}-03$ & $\mathrm{C}, \mathrm{I}$ & & & $5.50 \mathrm{E}-03$ \\
\hline & $8^{*}$ & $3.80 \mathrm{E}-01$ & & $8.80 E-05$ & TC & \% & & $3.80 E-01$ \\
\hline & $13^{*}$ & $3.00 \mathrm{E}-03$ & & 1.53E-01 & $1, C$ & & & $1.56 \mathrm{E}-01$ \\
\hline & $14^{*}$ & $5.40 \mathrm{E}-01$ & & 8.00E-03 & $\mathrm{C}$ & & & $5.48 \mathrm{E}-01$ \\
\hline & $22^{\star}$ & $1.08 \mathrm{E}+00$ & -4 & 4.41E-01 & $\mathrm{I}, \mathrm{Tc}$ & & & $1.52 E+00$ \\
\hline & $24^{\star}$ & H & & $3.00 \mathrm{E}-03$ & $\mathrm{C}$ & & & $3.00 \mathrm{E}-03$ \\
\hline & $27^{\star}$ & $1.32 \mathrm{E}+00$ & 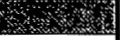 & 1.11E-01 & I, C & 2. & & $1.43 E+00$ \\
\hline & $29^{*}$ & 8.37E-01 & $8.22 \mathrm{E}-03$ & $5.41 \mathrm{E}-02$ & Tc & 1.04E-01 & $\mathrm{C}, \mathrm{Tc}$ & $1.00 \mathrm{E}+00$ \\
\hline & 33 & 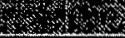 & $6.30 \mathrm{E}=03$ & H, & & 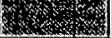 & & $6.30 \mathrm{E}-03$ \\
\hline
\end{tabular}

"Closed Trenches

**Trenches containing HICs or stabilized waste 
HNF-3762, Rev. 0

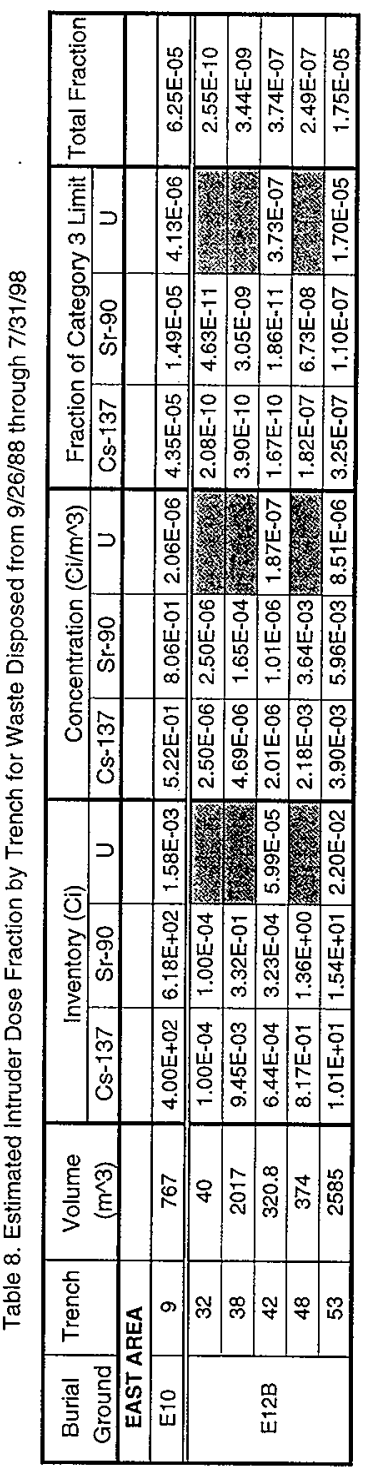




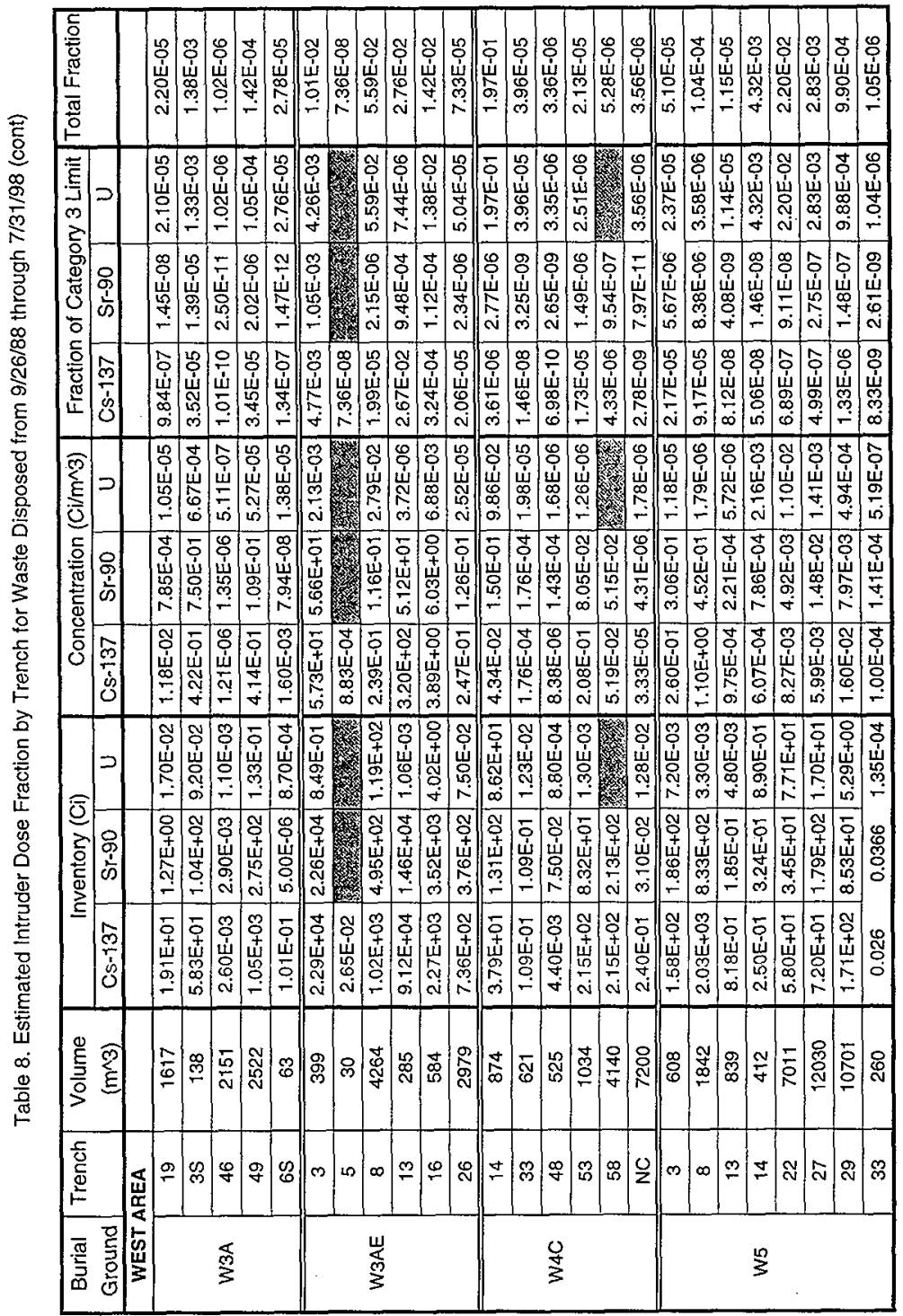


HNF-3762, Rev. 0

Table 9. Comparison of Dose/Flux Estimates with Performance Objectives

\begin{tabular}{|l|l|l|l|c|}
\hline \multirow{2}{*}{ Performance Objectives } & \multicolumn{2}{|c|}{ Exposure Pathway } & \multicolumn{3}{|c|}{ Estimated Dose or Flux* } \\
\cline { 3 - 5 } & & West Area & $218-\mathrm{E}-10$ & $218-\mathrm{E}-12 \mathrm{~B}$ \\
\hline $25 \mathrm{mrem} / \mathrm{yr}$ & groundwater, all pathways & $1.65^{\star *}$ & 0.016 & 0.0034 \\
\hline $4 \mathrm{mrem} / \mathrm{yr}$ & groundwater, drinking & $0.69^{\star *}$ & $5.88 \mathrm{E}-03$ & 0.00202 \\
\hline $100 \mathrm{mrem}(500 \mathrm{yr})$ & post-drilling intruder & 1.8 & 0.0063 & 0.0009 \\
\hline $20 \mathrm{pCi} / \mathrm{m} / 2 / \mathrm{s}$ at $10,000 \mathrm{yr}$ & radon emission & 0.033 & 0.000017 & $4.30 \mathrm{E}-05$ \\
\hline $10 \mathrm{mrem} / \mathrm{yr}$ & air contamination & Nil & Nil & Nil \\
\hline
\end{tabular}

* All estimates are made assuming Category 3 conditions as the final state of the LLBG. Potential doses from current and projected inventory are summed. All projected inventory and associated dose is assumed to go into the West Area LLBG. Units of measure of dose/flux values are the same as the corresponding performance objective.

** The majority of these doses are derived from projected iodine inventories $(0.32$ and $0.576 \mathrm{mrem} / \mathrm{yr}$ for the drinking water and all pathways scenarios, respectively). This dose projection estimates waste form performance to reduce the projected dose from iodine sources. If such waste is presented for disposal, some form of disposal requirement will be imposed to greatly reduce the the potential dose from this source. Prediction of the eventual dose estimate is highly uncertain. 


\section{DISTRIBUTION SHEET}

To

Distribution

Project TitteMork Order

1997-98 Annual Review ofthe 200 East \& West Area LLBG PA Analyses

Name

R.D. Hildebrand

R. Khaleel

C.T. Kincaid

P.J. Macbeth

F.M. Mann

G.L. Sinton

M.I. Wood

Central Files

DOE/RL Reading Rm.

HANFORD TECH. LIB.
From

M.I. Wood
Page 1 of 1

Date

EDT No. 618526

ECN No. N/A

\begin{tabular}{c|c|c|c|c} 
MSIN & $\begin{array}{c}\text { Text } \\
\text { With All } \\
\text { Attach. }\end{array}$ & Text Only & $\begin{array}{c}\text { Attach./ } \\
\text { Appendix } \\
\text { Only }\end{array}$ & $\begin{array}{c}\text { EDT/ECN } \\
\text { Only }\end{array}$ \\
\hline
\end{tabular}

